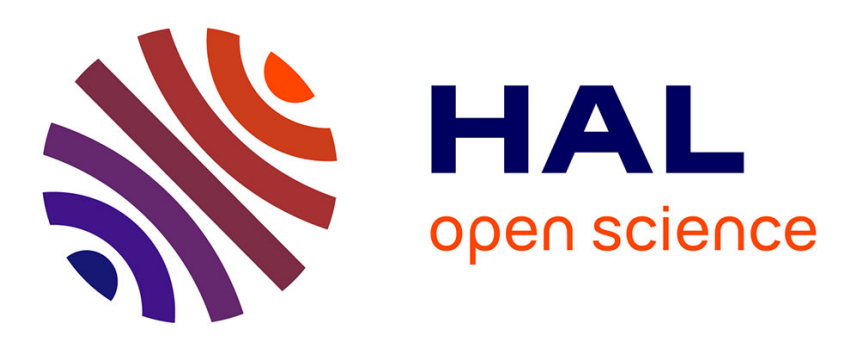

\title{
Multi-elemental concentrations in the tissues of the oceanic squid Todarodes filippovae from Tasmania and the southern Indian Ocean
}

Jessica Kojadinovic, Christine H. Jackson, Yves Cherel, George D. Jackson, Paco Bustamante

\section{To cite this version:}

Jessica Kojadinovic, Christine H. Jackson, Yves Cherel, George D. Jackson, Paco Bustamante. Multielemental concentrations in the tissues of the oceanic squid Todarodes filippovae from Tasmania and the southern Indian Ocean. Ecotoxicology and Environmental Safety, 2011, 74 (5), pp.1238-1249. 10.1016/j.ecoenv.2011.03.015 . hal-00599931

\section{HAL Id: hal-00599931 https://hal.science/hal-00599931}

Submitted on 11 Jun 2011

HAL is a multi-disciplinary open access archive for the deposit and dissemination of scientific research documents, whether they are published or not. The documents may come from teaching and research institutions in France or abroad, or from public or private research centers.
L'archive ouverte pluridisciplinaire $\mathbf{H A L}$, est destinée au dépôt et à la diffusion de documents scientifiques de niveau recherche, publiés ou non, émanant des établissements d'enseignement et de recherche français ou étrangers, des laboratoires publics ou privés. 
Multi-elemental concentrations in the tissues of the oceanic squid Todarodes filippovae from Tasmania and the southern Indian Ocean

Jessica Kojadinovic ${ }^{\mathrm{a}}{ }$, Christine H. Jackson ${ }^{\mathrm{b}}$, Yves Cherel ${ }^{\mathrm{c}}$, George D. Jackson ${ }^{\mathrm{b}}$ and Paco Bustamante $^{\text {a }}$

${ }^{a}$ Littoral Environnement et Sociétés (LIENSs), UMR 6250 CNRS-Université, 2 rue Olympe de Gouges, Université de La Rochelle, 17042 La Rochelle, France

b Institute of Antarctic and Southern Oceanic Studies, University of Tasmania, Private Bag 77, Hobart, TAS, 7001, Australia

c Centre d'Etudes Biologiques de Chizé, UPR 1934 du CNRS, BP 14, 79360 Villiers-en-Bois, France

*Corresponding author. Email address: jessica.kojadinovic@gmail.com

Present address: Clos Saint Jean, Chemin de Castagnet, 64160 Barinque, France, Tel.: +33 (0)5 24 361346 (Jessica Kojadinovic). 
Abstract : This study investigates 14 elements (Ag, As, Cd, Co, Cr, Cu, Fe, Hg, Mn, Ni, Pb, Se, V and $\mathrm{Zn}$ ) in the tissues of the oceanic ommastrephid squid Todarodes filippovae from waters surrounding Ile Amsterdam (southern Indian Ocean) and Tasmania (Australia). As for other cephalopod species, the digestive gland and branchial hearts showed the highest concentrations of many elements ( $\mathrm{Ag}, \mathrm{Cd}, \mathrm{Se}, \mathrm{V}$ and $\mathrm{Zn}$, and $\mathrm{Cr}$ and $\mathrm{Ni}$ respectively) highlighting their role in bioaccumulation and detoxification processes. With the exception of $\mathrm{As}$ and $\mathrm{Hg}$, the muscles showed relatively low trace element concentrations. Squid size was positively correlated to Ag, As, $\mathrm{Cd}, \mathrm{Hg}$ and $\mathrm{Zn}$ concentrations in Tasmanian squid and negatively correlated to all but $\mathrm{Hg}$ and $\mathrm{Zn}$ concentrations in Ile Amsterdam squid. Furthermore, no differences in elemental concentrations were noted between sexes. There were, however, some differences between mated and non-mated females from Tasmania. Comparing elemental concentrations in squid from both islands, higher concentrations of $\mathrm{Cd}, \mathrm{Co}, \mathrm{Cr}, \mathrm{Ni}, \mathrm{Pb}$ and $\mathrm{V}$ in squid sampled in Ile Amsterdam reflect different exposure conditions. When considering T. filippovae as a dietary resource for humans it should be noted that, given their $\mathrm{Hg}$ content, squids from Ile Amsterdam are not recommended for consumption on a regular basis. Moreover, regardless of the squid's origin, digestive glands should be avoided as $\mathrm{Cd}$ and $\mathrm{Hg}$ concentrations were above the European Union authorized limits in these organs.

Key words: Cephalopod; Southern Indian Ocean; Tasmania; Metals; Bioaccumulation; Consumption guidelines.

\section{Introduction}

Trace elements in cephalopods have received increasing attention in recent decades, particularly in Europe and in Japan, as these molluscs play a major role both as predator and prey in marine ecosystems (Boyle and Rodhouse, 2005), and are known to accumulate large quantities of Cd that can be transferred to higher trophic levels (e.g. Bustamante et al., 1998a; Dorneles et al., 2007). Cephalopods also represent an increasing resource for humans (Piatkowski et al., 2001). Historically, the consumption of cephalopod products has been highest in countries of south-east Asia (e.g. Japan) and these countries still predominate in fisheries for cephalopods as well as in developing new technologies for catching them. In European waters, cephalopods have traditionally been a minor catch, although locally important in some southern European countries such as Portugal, Italy, Spain and Greece where cephalopods are high in local diets (Payne et al., 2006). However their importance to European fisheries is increasing with the decline in traditional finfish 
stocks across the globe. For instance in the English Channel between 1983 and 2003, total catches of cephalopods increased by almost 300\%, from 8000 to 23000 tonnes (Payne et al., 2006). Cephalopod fisheries are also becoming more important in other parts of the world, with the example of total cephalopod catches in Chile increasing by more than 5000\% from 69 tonnes in 1978 to 3503 tonnes in 1996 (Rocha and Vega, 2003). This global fishery effort is likely to further increase in the next decade and species from remote areas could represent new fishery targets.

Besides their important ecological role, cephalopods display relatively short life spans, typically from one to two years in most of the targeted species. For this reason, they are of major interest for monitoring variations of pollutant concentrations in the environment as the accumulated concentrations in the cephalopod tissues reflect the bioavailability and metal variations in their immediate environment over a relatively short time scale (Rossi et al., 1993; Miramand et al., 2006). Indeed trace element analyses in marine organisms are commonly used to reflect the ambient concentrations, providing an integrated information over time according to the biological half life of elements in animals' tissues (e.g. Bustamante et al., 2008; Hédouin et al., 2009). This approach is particularly useful when trace elements are present at very low concentrations in the environment as it occurs in the Austral Ocean (Honda et al., 1987; Fitzwater et al., 2000; Sañudo-Wilhelmy et al., 2002) and to compare different locations (Rainbow, 1995; Warnau et al., 1998).

Most of the studies concerning metal bioaccumulation have focused on species from the northern hemisphere, while very little data has been reported for cephalopods in the southern hemisphere. To the best of our knowledge, these studies are limited to selected metals such as $\mathrm{Cd}, \mathrm{Cu}$ and $\mathrm{Zn}$ (e.g. Bustamante et al., 1998b; Dorneles et al., 2007). In the Southern Ocean the importance of cephalopods in trophic webs is exacerbated as squid can occupy the ecological niche of epipelagic fish (Rodhouse and White, 1995).

Although species of the genus Todarodes are particularly common in the northern part of this ocean, there is a paucity of biological information for the genus, particularly in relation to metal concentrations. Similarly there are surprisingly few data on metals for the well studied Japanese squid, Todarodes pacificus (Tanaka et al., 1983; Ichihashi et al., 2001b; Oikawa et al., 2003; Kim et al., 2008). Records of metal concentrations in T. filippovae, which has a vast but remote distribution zone, are to our knowledge nonexistent. 
This paper describes the bioaccumulation and tissue distribution of 14 trace elements (Ag, As, Cd, $\mathrm{Co}, \mathrm{Cr}, \mathrm{Cu}, \mathrm{Fe}, \mathrm{Hg}, \mathrm{Mn}, \mathrm{Ni}, \mathrm{Pb}, \mathrm{Se}, \mathrm{V}$ and $\mathrm{Zn}$ ) in T. filippovae from waters neighboring the Subtropical Front ${ }^{1}$ in the northern part of this species' distribution zone. These elements were selected as they represent, on one hand common essential elements accumulated by marine organisms, on the other hand non-essential elements the most likely to be hazardous to the squid's health and to that of its predators, including humans. The uniformity of elemental concentrations within this area is tested by comparing the results from two sampling zones located in the southern Indian Ocean and the southern Pacific Ocean (waters surrounding Ile Amsterdam and Tasmania, respectively) where T. filippovae appears to be the most abundant ommastrephid species (Dunning, 1993). Furthermore, because T. filippovae is believed to have some fishery potential, the elemental concentrations obtained in this study are analyzed within the framework of metal concentrations associated with health risks to humans.

\section{Materials and methods}

\subsection{Todarodes filippovae}

Todarodes filippovae (Adam 1975) is a large epipelagic ommastrephid squid that can reach $50 \mathrm{~cm}$ (mantle length), although it commonly measures between 20 and $40 \mathrm{~cm}$ (Rodhouse, 1998). It is characterized by a circum-polar distribution in the Southern Ocean from sub-Antarctic waters to slightly north of the Subtropical Front (south of $35^{\circ} 73 \mathrm{~S}$ ), in association with high velocity currents (Dunning and Wormuth, 1998; Jackson et al., 2007). This oceanic species occurs mostly between the surface and $200 \mathrm{~m}$ in depth, in the open ocean up to the continental slope, and appears not to extend into shelf waters (Rodhouse, 1998). Its life cycle is thought to be about a year. Spawning occurs in the Tasman Sea and off South Africa and probably takes place in the austral autumn and winter (Rodhouse, 1998; Jackson et al., 2007). Todarodes species are opportunistic and will feed on fish as well as squid, or even have cannibalistic tendencies (Boyle and Rodhouse, 2005). Indeed, $T$. 
filippovae feeds on myctophids and squid in Tasmanian waters (Jackson et al., 2007). Todarodes species are likely to be an important part of the ecosystem in the Southern Ocean as a number of vertebrates prey on them including marine mammals (such as the sperm whale Physeter macrocephalus and the southern elephant seal Mirounga leonina), fish (e.g. the haddock Merluccius australis) and seabirds (e.g. albatrosses Diomedea melanophrys) (Rodhouse, 1998; Cherel et al., 2002; Jackson et al., 2007). Although research on species identification, stock structure, and most aspects of its biology is still needed, T. filippovae is believed to have some fishery potential, with commercially viable catch rates having been reported in the Tasman Sea (Rodhouse, 1998). First taken as bycatch to the Japanese jig fishery for Nototodarus sloani off New Zealand and southern Australia, it started being caught in commercial quantities off northeast Tasmania in 1978. In this region, it is the most abundant ommastrephid in the Subtropical Front and in slope waters off southeastern Australia (Dunning, 1993).

\subsection{Sampling and preparation}

T. filippovae were sampled from two locations, approximately $5000 \mathrm{~km}$ apart, both situated slightly north of the Subtropical Front, in the northern part of the species distributional zone. The first location, in the Indian Ocean, lies roughly centered between the southern tip of Africa and Australia. Twenty four individuals were collected from the research vessel La Curieuse during a cruise undertaken in April 2000. Squids were taken from 22 pelagic trawls (13 - $380 \mathrm{~m})$ during five consecutive nights in oceanic waters between $44^{\circ} \mathrm{S}, 76^{\circ} \mathrm{E}$, and Saint Paul and Amsterdam islands $\left(38^{\circ} \mathrm{S}, 78^{\circ} 105 \mathrm{E}\right)$. Secondly, in the south Pacific Ocean, samples were obtained from waters around Tasmania $\left(42^{\circ} 00^{\prime} \mathrm{S}, 147^{\circ} 10700^{\prime} \mathrm{E}\right)$ which is situated off the south-east corner of the Australian mainland. Thirty two specimens were trawled in waters south-east of Tasmania in February/March

$40^{\circ} \mathrm{S}$ and reaches the west coast of South America near $30^{\circ} \mathrm{S}$ (American Meteorology Society, 2010; Wikimedia, 2010). 
and July/August 2005. Samples were frozen in plastic bags, at $-20^{\circ} \mathrm{C}$, on board the sampling vessels.

Individual squid were defrosted and dorsal mantle length (ML) was measured to the nearest millimeter $(\mathrm{mm})$. The total weight of each squid as well as the weight of the ovary or testis, digestive gland, gills and branchial hearts were weighed to the nearest gram (g). Significantly larger cephalopods were collected from Tasmanian waters (Table 1). Individuals were also sexed and females were examined as to whether they had recently mated. Subsamples of mantle muscle and digestive gland as well as the gills and branchial hearts were removed from all squid then freezedried, blended and ground to a fine powder to prepare for elemental determination. A subsample of the gonad was also removed from the Tasmanian squid and prepared in the same way.

\subsection{Metal analysis}

The metal analyses in samples from both study sites were realized simultaneously in the same batches of analyses. The total $\mathrm{Hg}$ concentrations in the powder obtained from the tissues were determined by analyzing Hg directly with an Advanced Mercury Analyzer (ALTEC AMA 254) on aliquots ranging from 5 to $50 \mathrm{mg}$ of dry sample weighed to the nearest $0.01 \mathrm{mg}$ (Bustamante et al., 2006b). The analysis of $\mathrm{Ag}, \mathrm{As}, \mathrm{Cd}, \mathrm{Co}, \mathrm{Cr}, \mathrm{Cu}, \mathrm{Fe}, \mathrm{Mn}, \mathrm{Ni}, \mathrm{Pb}, \mathrm{Se}, \mathrm{V}$ and $\mathrm{Zn}$ required an extra step in the preparation protocol. From 20 to $300 \mathrm{mg}$ of each sample were microwave digested in a mixture of $3 \mathrm{ml}$ of suprapure nitric acid (VWR/Merck) and $1 \mathrm{ml}$ of suprapure chloridric acid (VWR/Merck), and then diluted to $25 \mathrm{ml}$ with deionized water. These 13 elements were then analyzed by Inductively Coupled Plasma Atomic Emission Spectrometry (Varian Vista-Pro ICPAES) and Mass Spectrometry (ICP-MS II Series Thermo Fisher Scientific) in all tissues but the gonads. To avoid metal contamination, all glass and plastic utensils used were washed with detergent, soaked in a bath of mixed nitric $\left(35 \mathrm{ml}^{-1}\right)$ and chlorhydric $\left(50 \mathrm{ml} . \mathrm{l}^{-1}\right)$ acids for a 
minimum of $24 \mathrm{~h}$, rinsed 3 times in deionized (Milli-Q quality) water and dried in an oven at $50^{\circ} \mathrm{C}$ before use.

Accuracy and reproducibility of the preparation were tested by preparing an analytical blanks and replicates of lobster hepatopancreas (TORT-2) and dog-fish liver (DOLT-3) reference standards (National Research Council, Canada) along with each set of samples. Recovery rates were respectively equal to $91 \pm 9 \%$ for $\mathrm{Ag}, 95 \pm 23 \%$ for $\mathrm{As}, 92 \pm 7 \%$ for $\mathrm{Cd}, 83 \pm 8 \%$ for $\mathrm{Co}, 105 \pm 40 \%$ for $\mathrm{Cr}, 94 \pm 8 \%$ for $\mathrm{Cu}, 87 \pm 8 \%$ for $\mathrm{Fe}, 100 \pm 3 \%$ for $\mathrm{Hg}, 96 \pm 14 \%$ for $\mathrm{Mn}, 95 \pm 15 \%$ for $\mathrm{Ni}, 109 \pm$ $23 \%$ for $\mathrm{Pb}, 154 \pm 23 \%$ for $\mathrm{Se}, 96 \pm 7 \%$ for $\mathrm{V}$, and $101 \pm 12 \%$ for $\mathrm{Zn}$. Element concentrations are expressed in $\mu \mathrm{g} \cdot \mathrm{g}^{-1}$ of dry weight $(\mathrm{dw})$.

\subsection{Data analysis}

Besides classical numerical summaries and plots, the 149 following statistical analyses were performed at the $95 \%$ confidence level while carefully observing the p-value in the analysis. First, ttests were used to assess whether the squid sampled in Tasmania were significantly different from those sampled in Amsterdam in terms of the biological measurements (Table 1). Second, one-way ANOVAs for paired samples were used to assess whether there were significant differences between concentrations of the same metal in up to five tissues. In addition, in order to test the significance of differences in As and $\mathrm{Cu}$ concentrations between gills and the others tissues of Tasmanian squid, we performed paired t-tests and adjusted their p-values using Bonferroni's correction (which is known to be a conservative method). Third, ANCOVAs, using the log-transformed mantle length as covariate, were used to test the effect of sex (in Amsterdam squid), of the mated status (in Tasmania squid) and of the geographic site on the log-transformed elemental concentrations. 
This section documents the concentrations of trace elements in the tissues of $T$. filippovae caught in Ile Amsterdam and Tasmanian waters (see Tables 2 and 3, and Figures 1, 2 and 3), as well as describes factors that were shown to influence trace element concentrations in this species. However, for some elements, concentrations were below the detection limits. In such cases (“< DL" symbol in Tables 2 and 3) the results were not included in any further analyzes.

\subsection{Organotropism}

The digestive gland contained the highest concentrations of $\mathrm{Ag}, \mathrm{Cd}$ and $\mathrm{Zn}$ of all the tissues analyzed, irrespective of geographic location. Similarly, the highest concentrations of $\mathrm{Co}$ and $\mathrm{Cu}$ as well as $\mathrm{Fe}$ were found in the digestive gland of squid form Ile Amsterdam and Tasmania respectively (Figures 1, 2 and 3). The branchial hearts had the highest concentrations of $\mathrm{Cr}$ and $\mathrm{Ni}$ in both locations along with the highest concentrations of $\mathrm{Hg}$ and $\mathrm{Fe}$ in Ile Amsterdam squid and Co in Tasmanian squid. However, the gills were the major accumulation tissues for $\mathrm{As}, \mathrm{Cu}$ and $\mathrm{Mn}$ in $T$. filippovae caught around Tasmania (for As $\mathrm{p}<0.01$ between gills and digestive gland and $\mathrm{p}<0.001$ between gills and muscle; for $\mathrm{Cu} p<0.001$ between gills each other tissues: branchial hearts, digestive gland and muscle; for $\mathrm{Mn} \mathrm{p}<0.01$ between gills and muscle). On the other hand, the highest concentrations of $\mathrm{Hg}$ in Tasmanian squid were found in the muscle. For the three tissues in which there were detectible concentrations of As, the highest amounts were found in the gills of the Tasmanian squid and in the muscle of the Ile Amsterdam squid. Furthermore, detectible concentrations of $\mathrm{Pb}$ were highest in the gills of Tasmanian squid but for Ile Amsterdam squid, the digestive gland had the highest concentration of $\mathrm{Pb}$. Levels of $\mathrm{Se}$ and $\mathrm{V}$ were highest in the digestive glands from both of the study areas. Overall, the digestive gland stands out as the tissue of greatest importance in terms of elemental accumulation followed by the branchial hearts, the gills and the muscle. 


\subsection{Squid biological variables}

Among the measurements taken on each individual (viz. mantle length, total weight, ovary weight, digestive gland weight, gills weight and branchial heart weight), mantle length was found to be the most correlated to the concentrations of trace elements (Table 4). Moreover mantle length was very well correlated to the weight measurements (data not shown) and was thus chosen as a covariate when testing (by means of ANCOVAs) the effect of sex, mated status and geographic site on elemental concentrations.

The influence of gender was tested only in Ile Amsterdam as there were no males among the squid collected in Tasmania. Jackson et al. (2007) have noted that males seemed better at avoiding the trawl nets than females. No significant difference in elemental concentrations was detected between male and female squid of equal mantle length (Table 5).

Mated females were found only from Tasmanian waters. The comparison of elemental concentrations between mated and non-mated females of similar sizes showed no significant differences in the branchial hearts, gills or gonads. However, some weak evidence was found for As and $\mathrm{Cu}$ in the muscle, and for $\mathrm{Cr}$ and $\mathrm{Mn}$ in the digestive glands (Table 5). There were lower concentrations of $\mathrm{Cu}$ and higher concentrations of $\mathrm{As}, \mathrm{Cr}$ and $\mathrm{Mn}$ in mated females (data not shown).

\subsection{Geography}

The size-normalized comparison of the squid sampled in Ile Amsterdam and in Tasmania indicated significant differences in concentrations of all elements but $\mathrm{Mn}$ and Se, although not for every 
element/tissue combination (Table 5). Levels were higher in Ile Amsterdam than in Tasmania for $\mathrm{Cd}, \mathrm{Cr}, \mathrm{Ni}$ and $\mathrm{Pb}$ in all tissues, and equal or higher for $\mathrm{Co}$ and $\mathrm{V}$ according to the tissue (Tables 2 and 3 and Figures 1, 2 and 3). On the contrary, concentrations were higher in Tasmania for As in all tissues, and equal or higher for $\mathrm{Cu}, \mathrm{Hg}$ and $\mathrm{Zn}$ according to the tissue. The results for $\mathrm{Ag}$ and $\mathrm{Fe}$ were opposite in different tissues. For Ag, concentrations in the digestive gland were highest in squid from Ile Amsterdam whereas, in the gills they were highest in squid from Tasmania. For Fe, concentrations in the branchial hearts were highest in squid from Ile Amsterdam whereas, in the digestive gland, they were highest in squid from Tasmania. Overall, particularly large differences in concentrations between both sites were observed for $\mathrm{Cd}, \mathrm{Co}, \mathrm{Cr}, \mathrm{Cu}$ in the gills, $\mathrm{Fe}$ in the branchial hearts and the digestive gland, for $\mathrm{Hg}$ in the muscle tissue and for $\mathrm{Ni}$ in the branchial hearts (Figures 1, 2 and 3).

\section{Discussion}

Trace element concentrations in cephalopods have received increasing attention over the last decades as these molluscs play a major role both as predators and prey in marine ecosystems, and are widely consumed by man (e.g. Boyle and Rodhouse, 2005; Pierce et al., 2008). Previous studies have demonstrated their ability to rapidly accumulate high concentrations of trace elements in their tissues making them good bioindicators of environmental levels but also a potential source of human intoxication (e.g. Storelli et al., 2006, 2010; Pernice et al., 2009). As in most marine animals, concentrations may vary with biological factors specific to an individual, a population or a species, or with environmental factors (Pierce et al., 2008). The impact of such factors on the elemental concentrations found in Todarodes filippovae are discussed hereafter in the aim to facilitate the future use of this species as a bioindicator of environmental element levels. Finally, the results are regarded from a human health perspective. 


\subsection{Metal distribution in the tissues}

Many studies highlight that in cephalopods, the digestive gland has a central role in the bioaccumulation of trace elements, particularly for toxic metals such as Ag and Cd (see e.g. Martin and Flegal, 1975; Ichihashi et al., 2001a; Bustamante et al., 2002b, 2004a; Miramand et al., 2006). The branchial hearts are considered as excretion tissues, allowing the depuration and/or the storage of various elements (e.g. Nardi and Steinberg, 1974; Guary et al., 1981; Bustamante et al., 2002b). Consequently, in most cephalopod species, these two tissues contain the highest concentrations of many trace elements. This was also the case in this study of T. filippovae, irrespective of location, particularly in relation to $\mathrm{Ag}, \mathrm{Cd}, \mathrm{Se}, \mathrm{V}$ and $\mathrm{Zn}$, and $\mathrm{Cr}$ and $\mathrm{Ni}$ that were concentrated in the digestive gland and the branchial hearts respectively. It is interesting to note that, in many marine animals, $\mathrm{Ag}, \mathrm{Cd}, \mathrm{Cu}, \mathrm{Hg}$ and $\mathrm{Zn}$ bind to metallothioneins as detoxification and homeostasis processes (Anan et al., 2002; Bustamante et al., 2004a). Although these phenomena are not well documented in cephalopods (Tanaka et al., 1983; Craig and Overnell, 2003; Bustamante et al., 2006a), the joint concentration of $\mathrm{Ag}, \mathrm{Cd}, \mathrm{Cu}$ and $\mathrm{Zn}$ in the digestive gland of $T$. filippovae may well be an indication that detoxification mechanisms exist to hinder the toxic action of both essential and non-essential metals in this species. The strongest metal concentration correlations were observed in the digestive gland between $\mathrm{Ag}, \mathrm{Cd}, \mathrm{Cu}$ and $\mathrm{Zn}$ in squid from Amsterdam (correlation coefficients ranging from 0.69 to 0.89 , with 266 p-values <0.001), and between $\mathrm{Ag}$ and $\mathrm{Cu}$ in squid from Tasmania $(r=0.79, \mathrm{p}<0.001)$. The correlations cited above may be the sign of the joint binding of these metals to metallothioneins.

Another alternative route for metal elimination in female squid is the transfer of metals to their eggs, as this has been observed in experimental conditions for Ag, Se and $\mathrm{Zn}$ (Lacoue-Labarthe et al., 2008). No significant differences in $\mathrm{Cd}$ and $\mathrm{Hg}$ concentrations between mated and non-mated females were observed in this study suggesting that these two elements are not likely to be excreted through the eggs in T. filippovae. The transfer to the eggs might however be specific to certain 
elements such as essential ones (Lacoue-Labarthe et al., 2008). Levels of $\mathrm{Cu}$ in muscle were found to be significantly lower in mated individuals than in non-mated ones suggesting a transfer of $\mathrm{Cu}$ from the muscle to the gonads in the mated females as this element is essential for the development of the hatchlings (Villanueva and Bustamante, 2006).

In individuals originating from Tasmania, the gills concentrated most of the $\mathrm{As}, \mathrm{Cu}$ and $\mathrm{Mn}$. The majority of the elements present in cephalopods are assumed to be incorporated by the diet as these carnivorous animals have a high feeding rate (Bustamante et al., 2002b; Villanueva and Bustamante, 2006; Bustamante et al., 2006c). However direct uptake of elements from seawater through the gills is also a known phenomenon in cephalopods (Bustamante et al., 2004b, 2006c). It has been verified in different species for elements such as $\mathrm{Ag}, \mathrm{Cd}$ and $\mathrm{Zn}$ (Ueda et al., 1985; Koyama et al., 2000; Bustamante et al., 2002a, 2004b) and suggested for elements such as $\mathrm{Cr}$, Fe and Ni (Miramand et al., 2006; Bustamante et al., 2008). It appears from the present results that seawater may also be a direct source of As and $\mathrm{Mn}$ in some cephalopods under certain conditions (in Ile Amsterdam the gills were not the target tissue for As). It would be interesting to further pursue this hypothesis as, to the best of our knowledge, there exist no experimental studies on the absorption of these elements via the gills. The results for $\mathrm{Cu}$ were quite striking, with concentrations, two, three and 58 fold higher in the gills than in the branchial hearts, the digestive glands and the muscles, respectively. Copper is however usually present in low concentrations in seawater (Watanabe et al., 1997). The most straightforward explanation for such a gill-oriented accumulation of this essential element is its association with haemocyanin. Indeed, $\mathrm{Cu}$ works as a respiratory pigment in haemocyanin, which is the typical dioxygen carrier for molluscs and crustaceans that represents $98 \%$ of blood protein in cephalopods (Ghiretti, 1966; D'Aniello et al., 1986). Due to the respiratory function of the gills, it would appear highly likely to observe a greater presence of haemocyanin and hence $\mathrm{Cu}$ in the gills. 
The muscle tissue of T. filippovae was characterized by the lowest concentrations of most trace elements. This result is consistent with data reported for other cephalopod species (Miramand and Bentley, 1992; Storelli and Marcotrigiano, 1999; Ichihashi et al., 2001b; Bustamante et al., 2008). There were two exceptions, for As and $\mathrm{Hg}$, which were accumulated mostly in the muscle of cephalopods from ${ }^{\wedge}$ Ile Amsterdam and Tasmania, respectively. Arsenic has been shown to have a tropism towards muscular tissues in cephalopods (Pernice et al., 2009), but few data exist on its speciation. The As accumulated in the muscle tissue of T. filippovae could be mostly present in its organic form, hence non toxic, but further research would need to be conducted to corroborate this possibility. A $\mathrm{Hg}$ organotropism towards muscle has also previously been described by various authors including (Bustamante et al., 2006b), who related it to the existence of a $\mathrm{Hg}$ excretion function of the digestive gland and/or a preferential redistribution of $\mathrm{Hg}$ (mostly in the organic form) to muscular tissues where it binds to sulphydryl groups of proteins. Such chemical transformations are also well described in fish in which virtually $100 \%$ of the $\mathrm{Hg}$ is in the methylated form (Bloom, 1992). Since food appears as the main pathway of exposure for $\mathrm{Hg}$ (Lacoue-Labarthe et al., 2009b) and T. filippovae mainly feeds on mesopelagic fish in both areas (Jackson et al., 2007, Cherel unpublished data), the reasons for such a difference in the accumulation processes between $T$. filippovae from Tasmania ( $\mathrm{Hg}$ mostly accumulated in the muscle) and those from Ile Amsterdam ( $\mathrm{Hg}$ mostly accumulated in the branchial hearts) appear unclear.

\subsection{Influence of biological variables}

The potential impact of certain biological factors are considered here, such as body and organ measurements, sex and whether or not the individual had mated that year. 
The most obvious result was the correlation between the size (viz. mantle length) of $T$. filippovae and the trace element concentrations found in its tissues (Table 4). Such an observation is common across a large spectrum of marine species. Most often, given the bioaccumulating properties of trace elements, their concentrations tend to increase with the size (and presumably age) of the individual. This was the case for $\mathrm{Ag}, \mathrm{As}, \mathrm{Cd}, \mathrm{Hg}$ and $\mathrm{Zn}$ in Tasmanian squid and for $\mathrm{Hg}$ and $\mathrm{Zn}$ in Ile Amsterdam squid. On the contrary, for all the other elements tested in squid from Ile Amsterdam, concentrations decreased with squid size. This denotes a greater tendency of these elements to accumulate in small sized animals rather than in larger ones. A plausible explanation for the negative correlations between these metals and squid size could be attributed to the marked modification in T. filippovae's diet during its life cycle. It is common for squid to experience a drastic change in diet during ontogeny, young squid consuming mainly crustaceans and older squid living primarily on fish (Pierce et al., 2008). This hypothesis concurs with recent findings stemming from isotopic studies on the very same animals used in this study, indicating the existence of dietary shifts from lower to higher trophic levels during growth (Cherel et al., 2009). Another explanation could be the existence of a "dilution" effect linked to the rapid increase of tissue mass due to growth (that is very rapid in cephalopods) with regards to proportionally lower intake of trace elements (Pierce et al., 2008).

\subsubsection{Sex and mated status}

Contrary to expectations, no differences in metal concentrations were noted between sexes in spite of differential growth rates enabling females to reach greater mantle lengths and weights than males (Jackson et al., 2007; Cherel et al., 2009). This suggests, however, that both sexes share the same physiology regarding uptake and depuration of trace elements, as previously suggested during exposure to radioisotopes of a range of metals in Sepia officinalis (Bustamante et al., 2002b, 2004b, 
2006c; Lacoue-Labarthe et al., 2009a). Additionally, this also suggests that males and females of similar sizes have a similar diet as the trophic pathway is the most important one for the majority of trace elements (Bustamante et al., 2002a; Lacoue-Labarthe et al., 2009a). Among females however, differences in muscular $\mathrm{Cu}$ concentrations and concentrations of $\mathrm{Cr}$ and $\mathrm{Mn}$ in the digestive gland, seem linked to the reproductive state (Table 5). Some of these differences could be due to a redistribution of these essential elements within the organism of the mated individuals.

\subsection{Influence of geography}

Among environmental factors, the geographical origin often has a considerable impact on trace element concentrations in cephalopods. The environment dictates the quantity of trace elements available, either directly by water absorption or indirectly through the ingestion of impregnated prey items.

For a recent review of metal concentrations in different cephalopod species from various origins refer to Bustamante et al. (2008), Table 3. Overall, the metal concentrations measured in the digestive gland of $T$. filippovae during this study are within the spectrum of values found in the digestive gland of cephalopods worldwide, often towards the lower end, specially for $\mathrm{Pb}$ and $\mathrm{V}$. With the exception of $\mathrm{Cd}$, the concentrations of non-essential elements resemble particularly those measured in the closest related species, T. pacificus and Stenoteuthis oualaniensis, sampled off Japan (western Pacific Ocean). Cadmium concentrations in Ile Amsterdam were higher than in most other cephalopods and similar to another ommastrephid species, Ommastrephes bartrami, sampled off the California coast (eastern Pacific Ocean). It is noteworthy that the concentrations of $\mathrm{Cr}$ and $\mathrm{Ni}$ reported here are among a very small body of information on these metals in cephalopods. In comparison, $\mathrm{Ni}$ and $\mathrm{Cr}$ concentrations in the digestive gland of $T$. filippovae were 3 to 30 , respectively 5 to 31 , times lower than concentrations measured in nautilus species from New 
Caledonia and the Vanuatu archipelago (Bustamante et al., 2000; Pernice et al., 2009). However, the concentrations of essential elements seem to be more variable among species in relation to the specific physiological needs of each animal rather than purely dependent on the environment. For instance, Pernice et al. (2009) showed that nautilus living in an environment enriched in Ni (from Ni mining in New Caledonia) did not have higher Ni concentrations than a closely related nautilus species living in an environment not Ni-enriched (Vanuatu archipelago).

In this study, T. filippovae showed significantly different elemental concentrations according to their location. Higher concentrations of $\mathrm{Cd}, \mathrm{Cr}, \mathrm{Ni}$ and $\mathrm{Pb}$ (and to a lesser extent $\mathrm{Co}$ and $\mathrm{V}$ ) in squid sampled in Ile Amsterdam compared to those caught in Tasmanian waters could be an indication that these elements are present in higher concentrations and/or more available in the Ile Amsterdam environment. On the contrary, concentrations of As (and to a lesser extent $\mathrm{Cu}, \mathrm{Hg}$ and $\mathrm{Zn}$ ) were highest in squid from Tasmania suggesting higher bioavailability of $\mathrm{As}$ (and potentially $\mathrm{Cu}, \mathrm{Hg}$ and Zn) in the Tasman sea. Differences in trophic behaviors and diets of T. filippovae between locations, if they exist, could also explain some of the site-related differences in metal concentrations.

\subsection{T. filippovae as a resource for man, a health viewpoint}

As mentioned previously T. filippovae is likely to be an important part of the ecosystem as it is preyed upon by a number of vertebrates, including man. Moreover, stocks of more broadly targeted squid species undergo great fluctuations in abundance from year to year and will potentially be declining under an increasing pressure as global fisheries look to new populations to exploit (Boyle and Rodhouse, 2005). From this standpoint, T. filippovae could soon become a new targeted ressource and the object of much larger fisheries than it is today. Consequently, it is of interest to relate the metal concentrations given here to concentrations associated to health risks in humans. Although they lack uniformity, guideline values are available for cephalopod consumers. The 
European Union has set regulations for $\mathrm{Cd}, \mathrm{Hg}$ and $\mathrm{Pb}$ (European Commission, legislations 2001/22/CE) and the United Nations has set regulations for As in addition to the elements mentioned above. Silver, $\mathrm{Cr}$ and $\mathrm{V}$ are very seldom reported in mollusc studies and have not been appointed international legal concentration limits. International legal thresholds are also nonexistent for essential elements even though, in excess, these elements can be toxic.

Mercury is of particular concern for human health. High exposures to $\mathrm{Hg}$, dependent on its form, can cause disruption of the nervous system, damage to brain functions, gastrointestinal tract and kidneys, DNA and chromosomal damage, allergic reactions and negative reproductive effects (such as sperm damage, birth defects and miscarriages) (Clarkson et al., 2003). Inorganic mercury occurring naturally, or from pollution, is converted to methyl-mercury ( $\mathrm{MeHg}$ ) by microorganisms and is biomagnified up the food chain. Consequently, a large percentage of $\mathrm{Hg}$ is present as toxic $\mathrm{MeHg}$ in the edible portions of squids consumed by man. The most widely established guideline value for $\mathrm{Hg}$ concentrations in cephalopods is $0.5 \mu \mathrm{g} \cdot \mathrm{g}^{-1} \mathrm{ww}$. This value, as those that will be given hereafter for $\mathrm{Cd}, \mathrm{Pb}$ and $\mathrm{As}$, corresponds to the guideline value for whole gutted animals which, for squid, corresponds mostly to muscle tissue. We have thus compared only the muscular $\mathrm{Hg}$ concentrations to this recommended limit and found that they exceeded $0.5 \mu \mathrm{g} . \mathrm{g}^{-1}$ ww in $52 \%$ of cases in Ile Amsterdam and in $9 \%$ of cases in Tasmania. The theories according to which "exposure to $\mathrm{MeHg}$ exceeding guideline levels leads to adverse effects" or "maternal $\mathrm{MeHg}$ exposures are directly associated with adverse child development" should be considered with a critical eye as they are somewhat incomplete. First, as for any metal, unless the dose absorbed is extremely high, the exposure must be prolonged for adverse effects to appear. Second, the toxicity of a metal may be decreased by its interaction with other elements, such as Se in the case of $\mathrm{Hg}$. Se is a nutritionally essential element that is present in all foods, but is particularly abundant in ocean fish and squid. A sufficient intake of Se offers a protective effect against $\mathrm{Hg}$ by their mutual irreversible binding (Parizek and Ostadalova, 1971; Iwata et al., 1973; Ohi et al., 1976; Whanger, 1992). For a detailed 
explanation of these biochemical processes refer to Ralston (2008). In order to better assess the true risk linked to $\mathrm{Hg}$ exposure, Kaneko and Ralston (2007) have proposed a new measure of seafood safety that takes the protective role of Se into account. It is called the Selenium Health Benefit Value (Se-HBV) and is based on the relative quantity of $\mathrm{Hg}$ versus Se. Using this index, the authors conclude that most varieties of ocean fish (Hg:Se ratio around 1:5) are safe to eat. Squids also tend to be rich in Se. In this study, the large differences in the levels of the detection limits for $\mathrm{Hg}$ and $\mathrm{Se}$ prevent $\mathrm{Hg}$ :Se ratio comparisons in the muscle tissue. However, relatively large amounts of Se were measured in other organs: $\mathrm{Hg}:$ Se ratios in the digestive gland were 1:27 and 1:41, in Tasmanian and Amsterdam squid respectively, and around 1:3 in gills in both locations. The toxicity of $\mathrm{Hg}$ in the studied squid might thus be lesser than what appears from a simple comparison to consumption guidelines. The use of Se-HBV should be considered in further studies dealing with $\mathrm{Hg}$ toxicity in relation to squid consumption. It is however important not to forget that, although Se offers protection from the toxic effects of $\mathrm{Hg}$, overexposure to Se can also cause damaging effects including serious neurologic, endocrine, and dermatologic effects (Agency for Toxic Substances and Disease Registry, 2003).

Cadmium is a stable, ubiquitous toxic metal, not abundant in its pure state in the environment. It mainly enters the humans organism via diet and inhalation (The Environmental Bureau of Investigation, 2009). Although the European Commission threshold concentration set for this metal in cephalopods is double that of $\mathrm{Hg}\left(1 \mu \mathrm{g} \cdot \mathrm{g}^{-1} \mathrm{ww}\right), \mathrm{Cd}$ is also highly toxic (e.g. Jarup, 2003). It mainly causes kidney diseases but can also affect the liver, lungs, bone, immune system, blood and nervous system following chronic inhalation or oral exposure, and is possibly carcinogenic (United States Environmental Protection Agency, 2007b). In the muscle of T. filippovae all concentrations were under this guideline value. The $1 \mu \mathrm{g} \cdot \mathrm{g}^{-1} \mathrm{ww}$ : guideline value for $\mathrm{Cd}$ refers to gutted squid, hence without their digestive glands. However, cephalopods tend to accumulate Cd mainly in their digestive gland, and in greater concentrations than most other marine zoological groups (Cognetti, 
1992). Moreover, in Japan the digestive gland, called kimo, is essential for making a widely consumed dish named shiokara. It is thus noteworthy that in the present study $100 \%$ of digestive glands from both study sites showed higher concentrations than the authorized $1 \mu \mathrm{g} . \mathrm{g}^{-1} \mathrm{ww}$.

Lead can accumulate in bone and affects practically all systems within the body (e.g. central nervous system, kidneys and blood cells) (United States Environmental Protection Agency, 2007a). The guideline value adopted by the European Commission for $\mathrm{Pb}$ in cephalopods is $1 \mu \mathrm{g} \cdot \mathrm{g}^{-1} \mathrm{ww}$. None of the individuals sampled had concentrations reaching this value. The $\mathrm{Pb}$ permissible value given above is more than 10 times higher than the maximum $\mathrm{Pb}$ concentration in muscle recorded during this study.

Arsenic is usually less of an issue in marine organisms than the metals previously discussed as, contrary to $\mathrm{Hg}$, organic forms of As are less toxic than its inorganic forms. Marine organisms are able to convert inorganic As into organic As compounds (Lunde, 1977). In fact, numerous studies on animals have indicated that As is an essential nutrient although its physiological role is open to conjecture (Uthus, 1992). Symptoms of acute intoxication in humans by inorganic As include severe gastrointestinal disorders, hepatic and renal failure, and cardiovascular disturbances, whereas chronic exposure causes skin pigmentation, hyperkeratosis, and cancers in the lung, bladder, liver, and kidney as well as skin (Gorby, 1994). The guideline value adopted by the World Health Organization for As in cephalopods is $2 \mu \mathrm{g}_{\mathrm{g}} \mathrm{g}^{-1} \mathrm{ww}$. . This value was not exceeded in the muscle of $T$. filippovae from this study. Moreover, the figures from this study refer to measures of total As, part of which is likely to be present in a non-toxic form. In a recent study on market fishes and squids, Lin et al. (2008) found that $87 \%$ of As in muscle was arsenobetaine, a form of As which is non-toxic and non-carcinogenic to humans, and is rapidly excreted through urine after ingestion. 
The dietary implications that stem from this study in terms of human consumption are the following. On one hand, As and $\mathrm{Pb}$ concentrations in T. filippovae caught around Ile Amsterdam or Tasmania are of no concern to human health. On the other hand, given the substantially high percentage $(52 \%)$ of individuals from Ile Amsterdam accumulating muscular $\mathrm{Hg}$ past the health guideline concentration, a frequent and regular consumption of T. filippovae originating from this area is not recommended. Moreover, regardless of the squid's origin, digestive glands should be avoided as $\mathrm{Cd}$ and $\mathrm{Hg}$ concentrations were past the authorized limits in all, or nearly all, the digestive glands analyzed. It should also be mentioned that fetuses, infants, and children are more vulnerable to $\mathrm{Hg}, \mathrm{Cd}, \mathrm{Pb}$ and $\mathrm{As}$ exposure than adults since these metals are more easily absorbed into growing bodies, they pass biological barriers (e.g. into the brain) more easily and children's brains and nervous systems are more sensitive to their damaging effects. Parents should thus be particularly aware of the quantity of seafood products, including T. filippovae, eaten by their children, and pregnant women should of course closely monitor their diet.

\section{Conclusion}

This study of the bioaccumulation and tissue distribution of 14 trace elements in T. filippovae from the southern Indian and Pacific oceans has not only confirmed a number of trace element behaviors observed in other cephalopod species from distinct locations, but has also highlighted patterns specific to this species in these areas. The digestive gland and branchial hearts of T. filippovae contained the highest concentrations of most trace elements whereas the muscle tissue was characterized by the lowest concentrations, irrespective of where the squid were caught. This familiar pattern in trace elemental studies was somewhat contradicted here by the exceptions of two elements, As and $\mathrm{Hg}$, that showed clear organotropisms towards muscle. Furthermore, the size of the squid was the most influential biological factor, followed by its geographic origin. Higher concentrations of $\mathrm{Cd}, \mathrm{Cr}, \mathrm{Ni}$ and $\mathrm{Pb}$ were noted in squid sampled in Ile Amsterdam compared to 
those caught in Tasmanian waters. Contrarily, concentrations of As were highest in squid from Tasmania. With respect to other cephalopod studies, metal concentrations of T. filippovae were overall within the spectrum of values found in cephalopods worldwide, often towards the lower end. However in the comparison of metal concentrations to human health consumption guidelines the major conclusion is that T. filippovae squid from both, Tasmania and Ile Amsterdam, contain levels of $\mathrm{Hg}$ and $\mathrm{Cd}$ often exceeding the recommended guidelines, especially in their digestive glands. Nevertheless, the non-negligible concentrations of Se also detected in these animals are to be kept in mind when considering $\mathrm{Hg}$ results because of the antagonistic effect of Se on $\mathrm{Hg}$ toxicity (Parizek and Ostadalova, 1971; Iwata et al., 1973; Ohi et al., 1976; Whanger, 1992; Ralston, 2008). The toxicity of other non-essential elements such as $\mathrm{Ag}$ and $\mathrm{Cd}$ is also probably diminished by their binding to metallothioneins.

\section{Acknowledgments}

We are grateful to G. Duhamel, P. Pruvost, the crew of the research vessel La Curieuse and the crew of the Adriatic Pearl from Tasmania who participated in the sampling effort. The field work at Amsterdam was supported financially and logistically by the Institut Polaire Français Paul Emile Victor (IPEV, Programme N`558 109, H. Weimerskirch). The analytical investigations were supported financially by the LIENSs (University of La Rochelle) and by a Hermon Slade grant awarded to G.D. Jackson. We also thank the referees for their helpful comments on the manuscript.

\section{References}

Agency for Toxic Substances and Disease Registry, 2003. Toxicological profile for selenium. Tech. rep., U.S. Department of Health and Human Services, Atlanta, GA.

American Meteorology Society, 2010. Glossary of meteorology. URL http://amsglossary.allenpress.com 
Anan, Y., Kunito, T., Sakai, H., Tanabe, S., 2002. Subcellular distribution of trace elements in the liver of sea turtles. Mar. Pollut. Bull. 45, 224-229.

Bloom, N. S., 1992. A survey of size-specific mercury concentrations in game fish from Maryland fresh and estuarine waters. Arch. Environ. Contam. Toxicol. 39 (1), 53-59.

Boyle, P. R., Rodhouse, P. G., 2005. Cephalopods: Ecology and Fisheries. Blackwell Science Ltd, Oxford.

Bustamante, P., Bertrand, M., Bouocaud-Camou, E., Miramand, P., 2006a. Subcellular distribution of $\mathrm{Ag}, \mathrm{Cd}, \mathrm{Co}, \mathrm{Cu}, \mathrm{Fe}, \mathrm{Mn}, \mathrm{Pb}$, and $\mathrm{Zn}$ in the digestive gland of the Common Cuttlefish Sepia officinalis. J. Shellfish Res. 25 (3), 987-993.

Bustamante, P., Caurant, F., Fowler, S. W., Miramand, P., 1998a. Cephalopods as a vector of the transfer of cadmium to top marine predators in the North-East Atlantic Ocean. Sci. Total Environ. $220,71-80$.

Bustamante, P., Cherel, Y., Caurant, F., Miramand, P., 1998b. Cadmium, copper and zinc in octopuses from the Kerguelen islands, Southern Indian Ocean. Polar Biol. 19, 264-271.

Bustamante, P., Cosson, R. P., Gallien, I., Caurant, F., Miramand, P., 2002a. Cadmium detoxification processes in the digestive gland of cephalopods in relation to accumulated cadmium concentrations. Mar. Environ. Res. 53 (3), 588 227-241.

Bustamante, P., Gonzalez, A., Rocha, F., Miramand, P., Guerra, A., 2008. Metal and metalloid concentrations in the giant squid Architeuthis dux from Iberian waters. Mar. Environ. Res. 66 (2), 278-287.

Bustamante, P., Grigioni, S., Boucher-Rodoni, R., Caurant, F., Miramand, P., 2000. Bioaccumulation of 12 trace elements in the tissues of the nautilus Nautilus macromphalus from New-Caledonia. Mar. Pollut. Bull. 40 (8), 688-696.

Bustamante, P., Lahaye, V., Durnez, C., Churlaud, C., Caurant, F., 2006b. Total and organic Hg concentrations in cephalopods from the North East Atlantic waters: influence of geographical origin and feeding ecology. Sci. Total Environ. 368 (2-3), 585-596. 
Bustamante, P., Morales, C. F., Mikkelsen, B., Dam, M., Caurant, F., 2004a. Trace element bioaccumulation in grey seals Halichoerus grypus from the Faroe Islands. Mar. Ecol. Prog. Ser. 267, 291-301.

Bustamante, P., Teyssié, J.-L., Danis, B., Fowler, S.W., Miramand, P., Cotret, O.,Warnau,M., $2004 b$. Uptake, transfer and distribution of silver and cobalt in tissues of the common cuttlefish Sepia officinalis at different stages of its life cycle. Mar. Ecol. Prog. Ser. 269, 185-195.

Bustamante, P., Teyssié, J.-L., Fowler, S.W., Cotret, O., Danis, B., Miramand, P., Warnau, M., 2002b. Biokinetics of zinc and cadmium accumulation and depuration at different stages in the life cycle of the cuttlefish Sepia officinalis. Mar. Ecol. Prog. Ser. 231, 167-177.

Bustamante, P., Teyssié, J.-L., Fowler, S. W., Warnau, M., 2006c. Assessment of the exposure pathway in the uptake and distribution of americium and cesium in cuttlefish Sepia officinalis at different stages of its life cycle. J. Exp. Mar. Biol. Ecol. 331 (2), 198-207.

Cherel, Y., Fontaine, C., Jackson, G. D., Jackson, 615 C. H., Richard, P., 2009. Tissue, ontogenic and sex-related differences in $\delta 13 \mathrm{C}$ and $\delta 15 \mathrm{~N}$ values of the oceanic squid Todarodes filippovae (Cephalopoda: Ommastrephidae). Mar. Biol. 156, 699-708.

Cherel, Y., Weimerskirch, H., Trouvé, C., 2002. Dietary evidence for spatial foraging segregation in sympatric albatrosses (Diomedea spp.) rearing chicks at îles Nuageuses, Kerguelen. Mar. Biol. 141, 1117-1129.

Clarkson, T. W., Magos, L., Myers, G. J., 2003. The toxicology of mercury - Current exposures and clinical manifestation. N. Engl. J. Med. 349, 1731-1737.

Cognetti, G., 1992. Colonization of stressed coastal environments. Mar. Pollut. Bull. 24 (1), 12-14. Craig, S., Overnell, J., 2003. Metal in squid, Loligo forbesi, adults, eggs and hatchlings. No evidence for a role for $\mathrm{Cu}$ - or Zn-metallothionein. Comp. Biochem. Physiol. 134C, 311-317.

D'Aniello, A., Strazzullo, L., D'Onofrio, G., Pischetola, M., 1986. Electrolytes and nitrogen compounds of body fluids and tissues of Octopus vulgaris Lam. J. Comp. Physiol. B 156 (4), 503509. 
Dorneles, P. R., Lailson-Brito, J., dos Santos, R. A., Silva da Costa, P. A., Malm, O., Azevedo, A. F., Machado Torres, J. P., 2007. Cephalopods and cetaceans as indicators offshore bioavailability of cadmium off Central South Brazil Bight. Environ. Pollut. 148, 352-359.

Dunning, M. C., 1993. Summer populations of Ommastrephes bartramii (Lesuer, 1821) and Todarodes filippovae Adam, 1975 (Cephalopoda: Ommastrephidae) from the Tasman Sea. In: Okutani, T., O'Dor, R. K., Kubodera, T. (Eds.), Recent advances in cephalopod fisheries biology. Tokai University Press, Tokyo, pp. 97-118.

Dunning, M. C., Wormuth, J. H., 1998. The Ommastrephid squid genus Todarodes: a review of systematics, distribution, and biology (Cephalopoda: Teuthoidea. Smithsonian contributions to zoology 2 (586), 385-391.

Fitzwater, S. E., Johnson, K. S., Gordona, R. M., Coale, K. H., Smith, Jr., W. O., 2000. Trace metal concentrations in the Ross Sea and their relationship with nutrients and phytoplankton growth. Deep Sea Res. II 47 (15-16), 3159-3179.

Ghiretti, F., 1966. Molluscan hemocyanins. In: Wilbur, K. M., Yonge, C. M. (Eds.), Physiology of Mollusca. Vol. II. Academic Press, London, New York, pp. 233-248.

Gorby,M. S., 1994. Arsenic in human medicine. In: Nriagu, J. O. (Ed.), Arsenic in the Environment, Part II: Human Health and Ecosystem Effects. John Wiley and sons, New York, pp. 1-16.

Guary, J. C., Higgo, J. J. W., Cherry, R. D., Heyraud, M., 1981. High concentration of transuranic and natural radioactive elements in the branchial hearts of the cephalopods Octopus vulgaris. Mar. Ecol. Prog. Ser. 4, 123-126.

Honda, K., Yamamoto, Y., Tatsukawa, R., 1987. Distribution of heavy metals in Antarctic marine ecosystem. In: Proc. NIPR Symp. Polar Biol. pp. 184-197.

Hédouin, L., Bustamante, P., Churlaud, C., Pringault, O., Fichez, R.,Warnau, M., 2009. Trends in concentrations of selected metalloid and metals in two bivalves from the SW lagoon of New Caledonia. Ecotox. Environ. Safety 72 (2), 372-381. 
Ichihashi, H., Kohno, H., Kannan, K., Tsumura, A., Yamasaki, S.-I., 2001a. Multielemental analysis of Purpleback Flying Squid using high resolution inductively coupled plasma-mass spectrometry (HR ICP-MS). Environ. Sci. Technol. 35 (15), 3103-3108.

Ichihashi, H., Nakamura, Y., Kannan, K., Tsumura, A., Yamasaki, S.-I., 2001b. Multi-elemental concentrations in tissues of Japanese common Squid (Todarodes pacificus). Arch. Environ. Contam. Toxicol. 41, 483-490.

Iwata, H., Okamoto, H., Ohsawa, Y., 1973. Effect of selenium on methylmercury poisoning. Research Commun. Chem. Pathol. Pharmacol. 5, 673-680.

Jackson, G. D., Wotherspoonand, S., Jackson, C. H., 2007. Temporal life history plasticity of the Southern Ocean squid Todarodes filippovae from waters off Tasmania, Australia. Mar. Biol. 155 (4), 575-584.

Järup, L., 2003. Hazards of heavy metal contamination. Brit. Med. Bull. 68, 167-182.

Kaneko, J. J., Ralston, N. V. C., 2007. Selenium and mercury in pelagic fish in the central North Pacific near Hawaii. Biol. Trace Element Res. 119, 242-254.

Kim, G. B., Kang, M. R., Kim, J. W., 2008. Specific accumulation of heavy metals in squid collected from offshore Korean waters: preliminary results for offshore biomonitoring and food safety assessment. Fish. Sci. 74 (4), 882-888.

Koyama, J., Nanamori, N., Segawa, S., 2000. Bioaccumulation of waterborne and dietary cadmium by Oval Squid, Sepioteuthis lessoniana, and its distribution among organs. Mar. Pollut. Bull. 40(11), 961-967.

Lacoue-Labarthe, T., Bustamante, P., Hörlin, E., Luna-Acosta, A., Bado-Nilles, A., Thomas-Guyon, H., 2009a. Phenoloxidase activation in the embryo of the common cuttlefish Sepia officinalis and responses to the $\mathrm{Ag}$ and $\mathrm{Cu}$ exposure. Fish Shellfish Immunol. 27 (3), 516-521.

Lacoue-Labarthe, T., Warnau, M., Oberhänsli, F., Teyssié, J.-L., Bustamante, P., $2009 b$. Bioaccumulation of inorganic $\mathrm{Hg}$ by the juvenile cuttlefish Sepia officinalis exposed to $203 \mathrm{Hg}$ radiolabelled seawater and food. Aquat. Biol. 6, 91-98. 
Lacoue-Labarthe, T., Warnau, M., Oberhänsli, F., Teyssié, J.-L., Jeffree, R., Bustamante, P., 2008. First experiments on the maternal transfer of metals in the cuttlefish Sepia officinalis. Mar. Pollut. Bull. 57(6-12), 826-831.

Lin, H.-T., Chen, S.-W., Shen, C.-J., Chu, C., 2008. Arsenic speciation in fish on the market. J. Food Drug Anal. 16(4), 70-75.

Lunde, G., 1977. Occurrence and transformation of arsenic in the marine environment. Environ. Health Perspect. 19, 47-52.

Martin, J. H., Flegal, A. R., 1975. High copper concentrations in squid livers in association with elevated levels of silver, cadmium, and zinc. Mar. Biol. 30(1), 51-55.

Miramand, P., Bentley, D., 1992. Concentration and distribution of heavy metals in tissues of two cephalopods, Eledone cirrhosa and Sepia offcinalis, from the French coast of the English Channel. J.Mar. Biol. 114(3), 407-414.

Miramand, P., Bustamante, P., Bentley, D., Koueta, N., 2006. Variation of heavy metal concentrations ( $\mathrm{Ag}, \mathrm{Cd}, \mathrm{Co}, \mathrm{Cu}, \mathrm{Fe}, \mathrm{Pb}, \mathrm{V}$, and $\mathrm{Zn}$ ) during the life cycle of the common cuttlefish Sepia officinalis. Sci. Tot. Environ. $\underline{361}(1-3), 132-143$.

Nardi, G., Steinberg, H., 1974. Isolation and distribution of adenochrome(s)_in Octopus vulgaris. Comp. Biochem. Physiol. B 15 (3), 453-461.

Ohi, G., Nishigaki, S., Seki, H., Tamura, Y., Maki, T., 1976. Efficacy of selenium in tuna and selenite in modifying methylmercury intoxication. Environ. Res. 12, 49-58.

Oikawa, S., Song, S.-J., Maeyama, T., Kishimoto, T., Tomura, K., Higuchi, H., 2003. Determination of trace elements in squid organs by inductively coupled plasma mass spectrometry and neutron activation analysis. Bunseki Kagaku 52 (8), 551-557.

Parizek, J., Ostadalova, I., 1971. The protective effect of small amounts of selenite in sublimate intoxication. Experientia 23, 142-143.

Payne, A. G., Agnew, D. J., Pierce, G. J., 2006. Trends and assessment of cephalopod fisheries. Fish. Res. 78 (1), 1-3. 
Pernice, M., Boucher, J., Boucher-Rodoni, R., Joannot, P., Bustamante, P., 2009. Comparative bioaccumulation of trace elements between Nautilus pompilius and $N$. macromphalus (Cephalopoda: Nautiloidea) from Vanuatu and New-Caledonia. Ecotox. Environ. Safety 72 (2), 365371.

Piatkowski, U., Pierce, G., Morais da Cunha, M., 2001. Impact of cephalopods in the food chain and their interaction with the environment and fisheries: an overview. Fish. Res. 52 (1-2), 5-10.

Pierce, G., Stowasser, G., Hastie, L., Bustamante, P., 2008. Geographic, seasonal and ontogenetic variation in cadmium and mercury concentrations in squid (Cephalopoda: Teuthoidea) from UK waters. Ecotox. Environ. Safety 70 (3), 422-432.

Rainbow, P., 1995. Biomonitoring of heavy metal availability in the marine environment. Mar. Pollut. Bull. 31, 183-192.

Ralston, N. V. C., 2008. Selenium health benefit values as seafood safety criteria. EcoHealth 5, 442455.

Rocha, F., Vega, M. A., 2003. Overview of cephalopod fisheries in Chilean waters. Fish. Res. 60 (1), $151-159$.

Rodhouse, P. G., 1998. Todarodes filippovae in the Southern Ocean: an appraisal for exploitation and management. In: Okutani, T. (Ed.), Large pelagic squids. Japan Marine Fishery Resources Research Center, Tokyo, pp. 207-215.

Rodhouse, P. G.,White, M. G., 1995. Cephalopods occupy the ecological niche of epipelagic fish in the Antarctic Polar Front Zone. Bio. Bull., Mar. Biol. Lab. 189 (2), 77-80.

Rossi, A., Pellegrini, D., Belcari, P., Barghigiani, C., 1993. Mercury in Eledone cirrhosa from the Northern Tyrrhenian Sea: contents and relations with life cycle. Mar. Pollut. Bull. 26 (12), 683-686. Sañudo-Wilhelmy, S. A., Olsen, K. A., Scelfo, J. M., Foster, T. D., Flegal, A. R., 2002 Trace metal distributions off the Antarctic Peninsula in the Weddell Sea. Marine Chem. 77 (2). 157-170. 
Storelli, M. M., Garofalo, R., Giungato, D., Giacominelli-Stuaer, R., 2010. Intake of essential and non-essential elements from consumption of octopus, cuttlefish and squid. Food. Add. Contam. B 3(1), 14-18.

Storelli, M. M., Giacominelli-Stuffler, R., Storelli, A., Marcotrigiano, G. O., 2006. Cadmium and mercury in cephalopod molluscs: Estimated weekly intake. Food. Add. Contam. 23(1), 25-30.

Storelli, M. M., Marcotrigiano, G. O., 1999. Cadmium and total mercury in some cephalopods from the South Adriatic Sea (Italy). Food Additives and Contam_inants 16(6), 261-265.

Tanaka, T., Hayashi, Y., Ishizawa, M., 1983. Subcellular distribution and binding of heavy metals in the untreated liver of the squid; comparison with data from the livers of cadmium and silverexposed rats. Experientia Cell. Mo1. Life Sei. 39(7), 746-748.

The Environmental Bureau of Investigation, 2009. The environmental bureau of investigation (EBI) contaminants: cadmium. Tech. Rep., Energy Probe Research Foundation. URL http://www.eprf.ca/ebi/contaminants/cadmium.html

Ueda, T., Nakahara, M., Nakamura, R., Suzuki, Y., Shimizu, C., 1985. Accumulation of ${ }^{65}$ Zn by octopus Octopus vulgaris. J. Radiat. Res. 26, 313-320.

United States Environmental Protection Agency, 2007a. Indoor air quality. Tech. rep., Washington, USA. URL http://www.epa.gov/iaq/lead.html

United States Environmental Protection Agency, 2007b. Technology transfer network air toxics web site. Tech. rep., EPA, Washington, USA. URL http://www.epa.gov/ttn/atw/hlthef/cadmium.html Uthus, E. O., 1992. Evidence for arsenic essentiality. J. Environ. Geochem. Health 14(2), 55-58. Villanueva, R., Bustamante, P., 2006. Composition in essential and non essential elements of early stages of cephalopods and dietary effects on the elemental profiles of Octopus vulgaris paralarvae. Aquaculture 261 (1), 225-240.

Warnau, M., Biondo, R., Temara, A., Bouquegneau, J. M., Jangoux, M., Dubois, P., 1998. Distribution of heavy metals in the echinoid Paracentrotus lividus (Lmk) from the Mediterranean Posidonia oceanica ecosystem: seasonal and geographical variations. J. Sea Res. 39, 267-280. 
Watanabe, T., Kiron, V., Satoh, S., 1997. Trace minerals in fish nutrition. Aquaculture 151 (1-4), 185-207.

Whanger, P. D., 1992. Selenium in the treatment of heavy metal poisoning and chemical carcinogenesis. J. Trace Elem. Electrolytes, Health Dis. 6, 209-221.

Wikimedia, F., 2010. Wikipedia, l'encyclopédie libre. URL http://fr.wikipedia.org/wiki/Accueil 


\section{Caption to figures}

Fig. 1. Levels of trace elements $\left(\mu \mathrm{g} \cdot \mathrm{g}^{-1} \mathrm{dw}\right)$ in Todarodes filippovae tissues from Tasmania and Amsterdam (DG: Digestive Gland; BrH: Branchial Hearts). To assess whether the differences in concentrations were significant, one-way ANOVAs for paired samples were performed. The corresponding $\mathrm{p}$-values are given above the boxplots.

Fig. 2. Continued from Figure 2. Levels of trace elements $\left(\mu \mathrm{g}_{\mathrm{g}} \mathrm{g}^{-1} \mathrm{dw}\right)$ in Todarodes filippovae tissues from Tasmania and Amsterdam (DG: Digestive Gland; BrH: Branchial Hearts). To assess whether the differences in concentrations were significant, one-way ANOVAs for paired samples were performed. The corresponding p-values are given above the boxplots.

Fig. 3. Continued from Figure 3. Levels of trace elements $\left(\mu \mathrm{g} \cdot \mathrm{g}^{-1} \mathrm{dw}\right)$ in Todarodes filippovae tissues from Tasmania and Amsterdam (DG: Digestive Gland; BrH: Branchial Hearts). To assess whether the differences in concentrations were significant, one-way ANOVAs for paired samples were performed. The corresponding p-values are given above the boxplots. 
TASMANIA
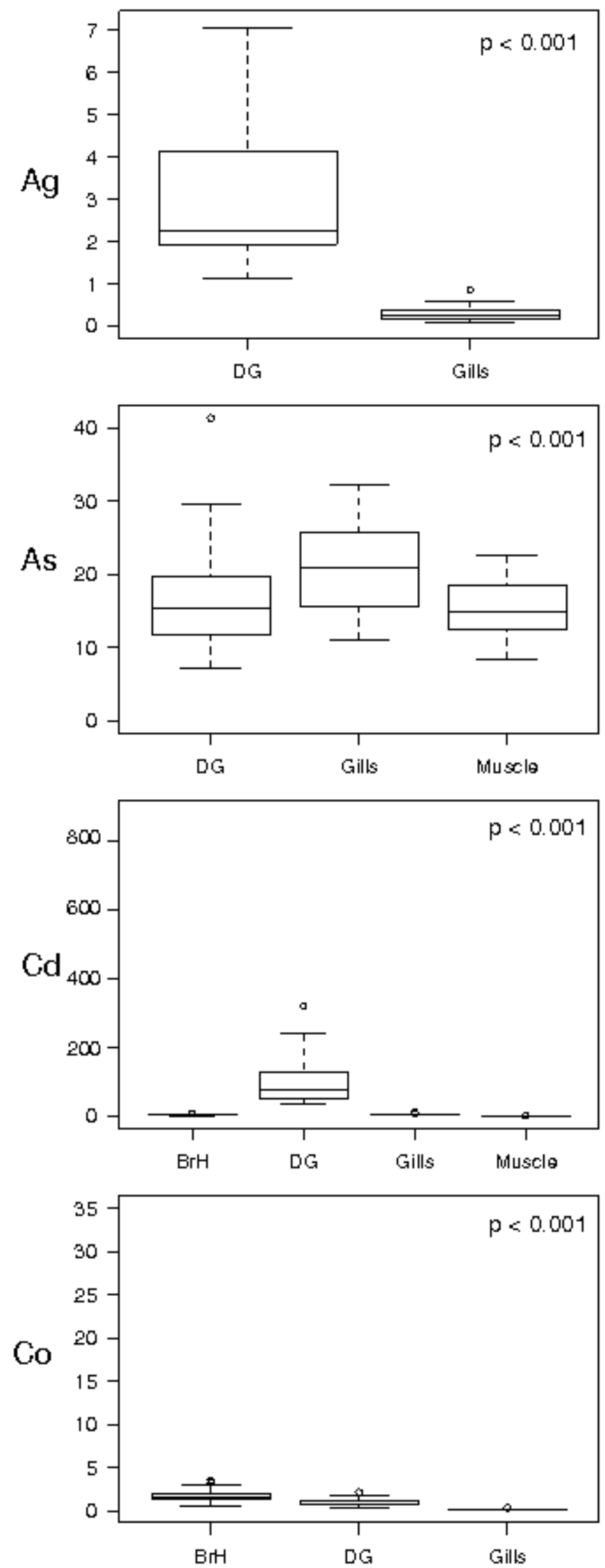

AMSTERDAM
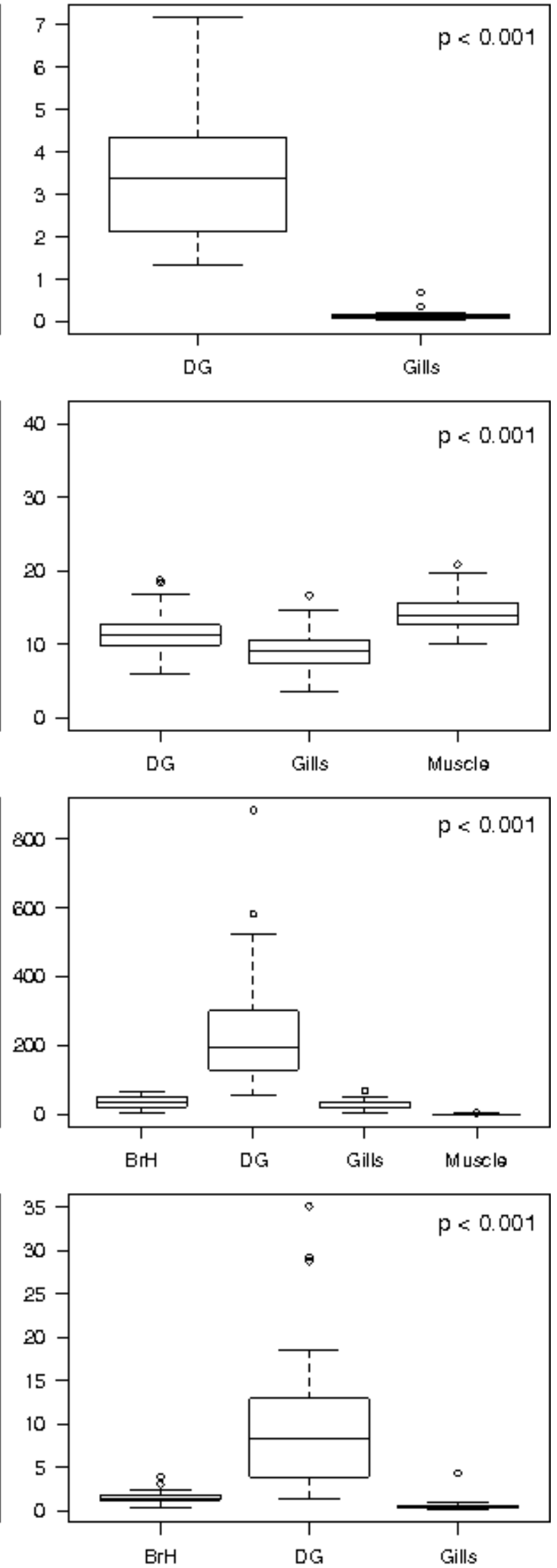

Fig. 1 
TASMANIA
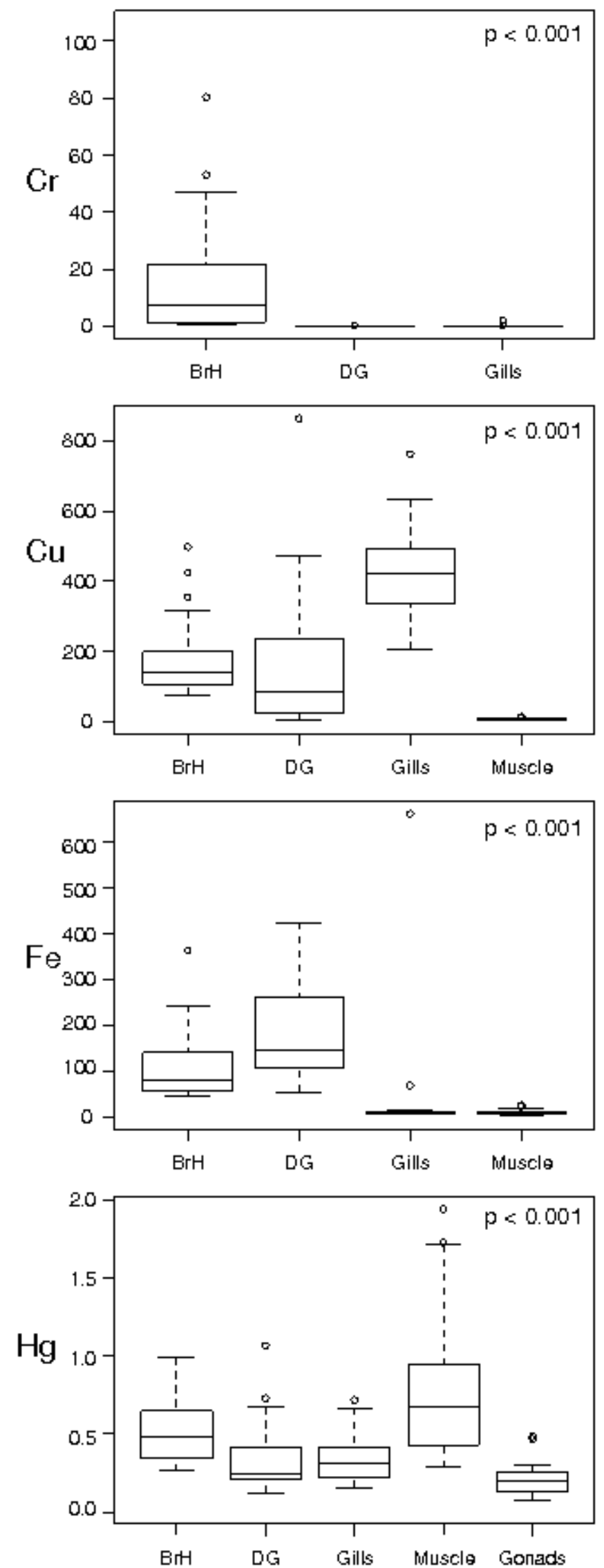

AMSTERDAM
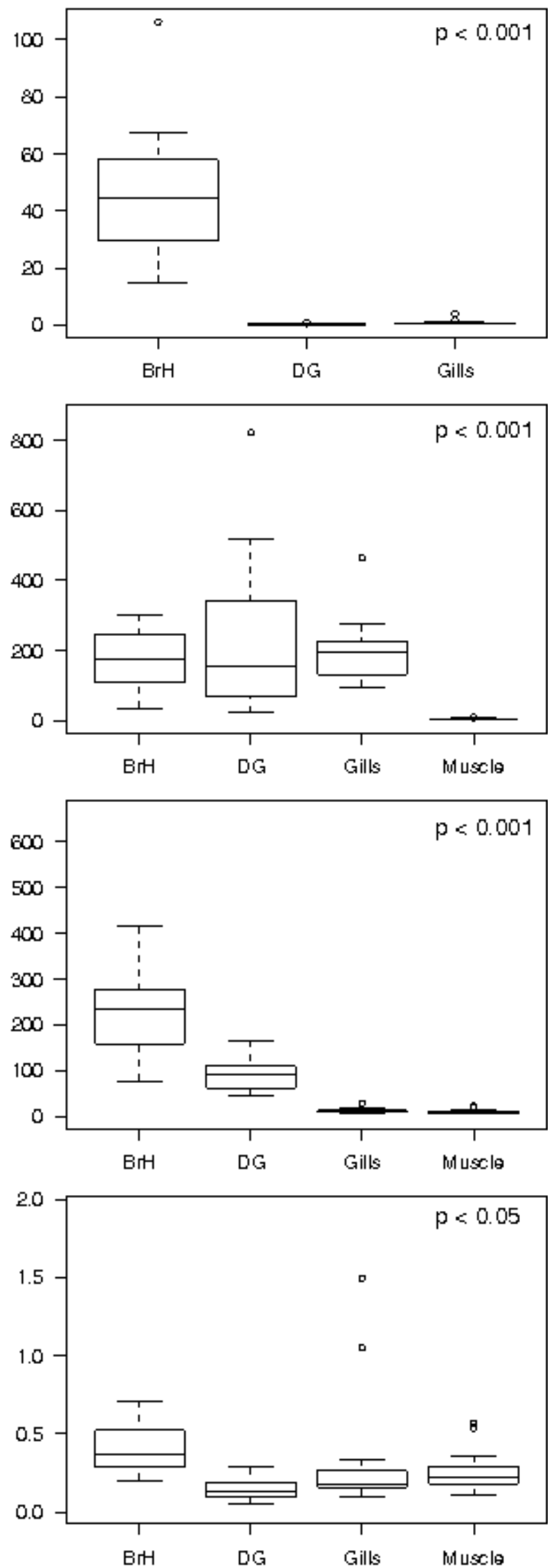

Fig. 2 
TASMANIA
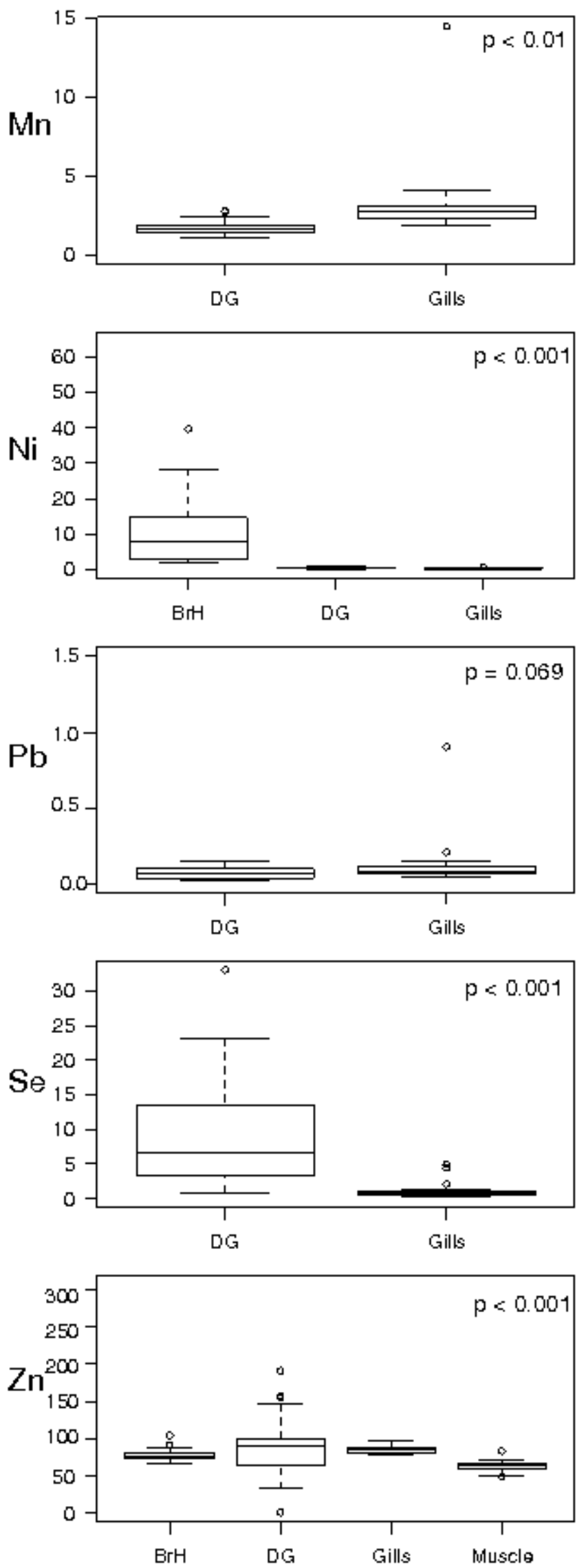

Fig. 3
AMSTERDAM
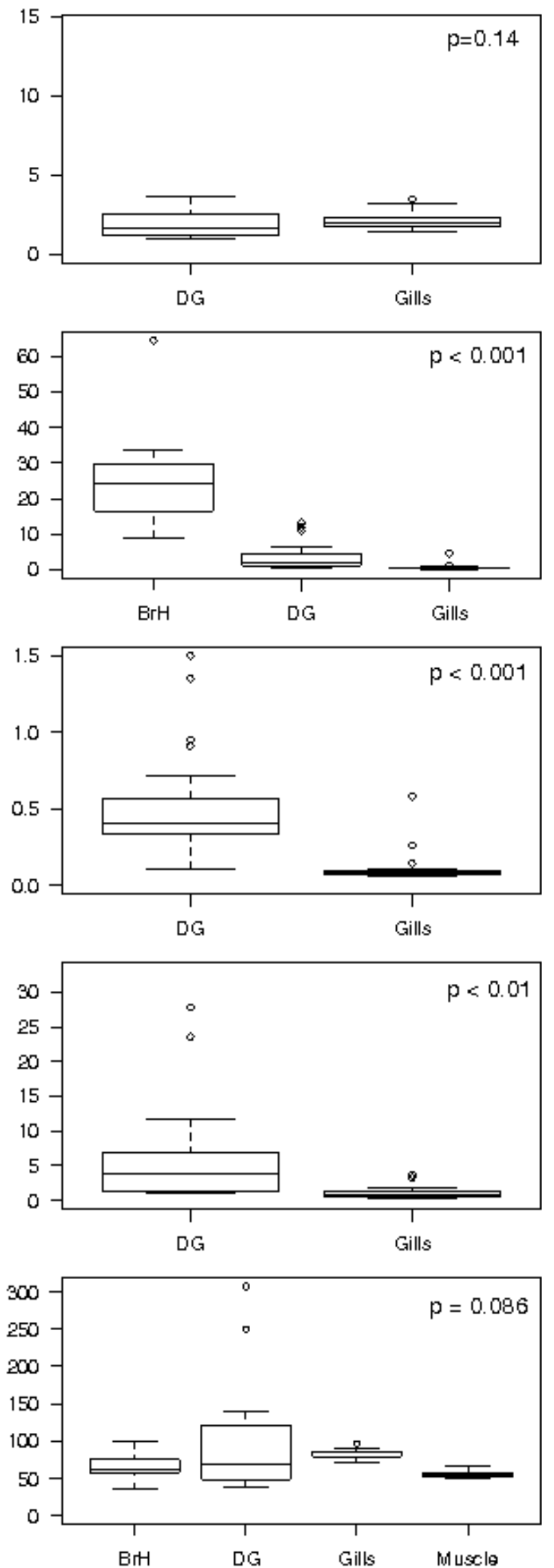


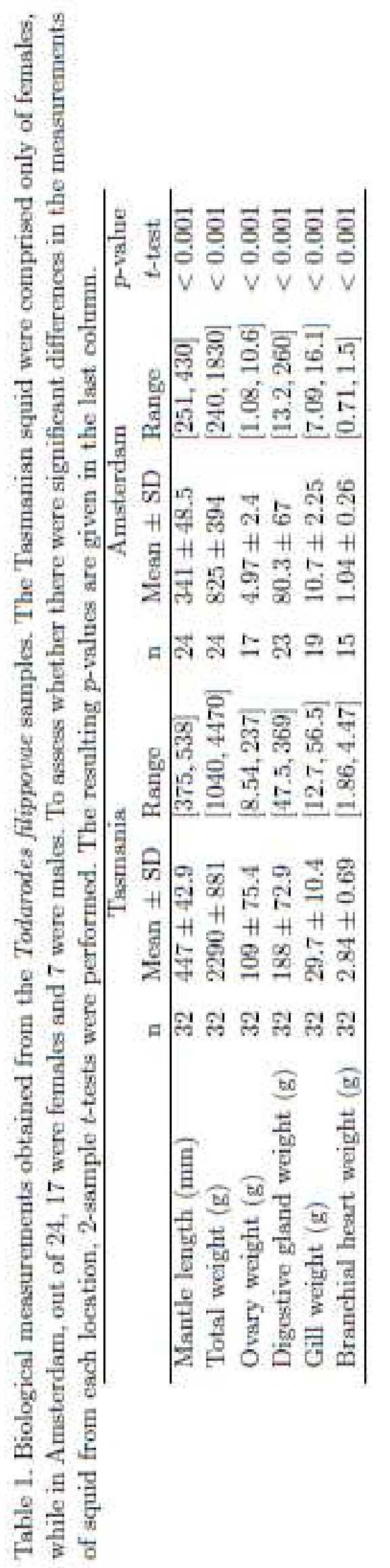


Thible 2

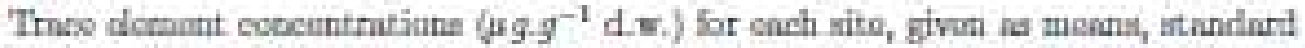

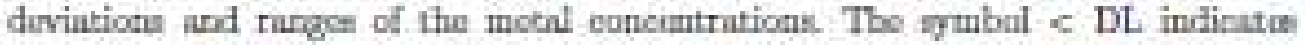
cockentratians briber dotoction limiles

\begin{tabular}{|c|c|c|c|c|c|c|c|}
\hline \multirow[b]{2}{*}{ Orgin } & \multirow[b]{2}{*}{ Mintal } & \multirow[b]{2}{*}{ in } & \multicolumn{2}{|c|}{ Thanninia } & \multicolumn{3}{|c|}{ Amitardem } \\
\hline & & & Mogi \pm 30 & Phnige & II. & Mrent $\neq 51$ & Rnisyi \\
\hline \multirow{14}{*}{$\begin{array}{l}\text { Briminhial } \\
\text { hearty }\end{array}$} & $\mathrm{Ag}$ & $M$ & $\because D L$ & & II & $D D$ & \\
\hline & $\mathrm{M}$ & 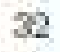 & $=D L$ & & 15i & $-\mathrm{DI}$ & \\
\hline & $\mathrm{CH}$ & 3 & $2 \mathrm{FH} \pm 1 \mathrm{H}$ & {$[90,7.14]$} & 15 & 34.19 .7 & {$[$ LIT, GL, T] } \\
\hline & $\mathrm{Co}$ & $n$ & $1 \pi \pm 0 \mathrm{fth}$ & {$[0,3.1]$} & If & $\perp A 1 \pm \| . M$ & T.J1, 399 \\
\hline & $\mathrm{Ct}$ & $x$ & $10, T \pm 19.9$ & D.4E, 84.4 & 1f. & $4 \tau_{1} 1 \pm 20.7$ & $14.7,100$ \\
\hline & $\mathrm{Cu}$ & $x$ & $179=100$ & {$[\pi L 1,4 M]$} & 14 & $179 \pm 8 \pi \mathrm{h}$ & $3.5,54$ \\
\hline & Fii & 3 & $111 \pm T .4$ & {$[4.1,364]$} & 10 & $28 \pm 86.6$ & MT, $4 \mid \mathrm{s}$ \\
\hline & $\mathrm{H}_{\mathrm{g}}$ & 10 & $051=021$ & {$[4,25,0.9]$} & 15 & $0.4 \pm 11.17$ & {$[0 \geq 1,0,1]$} \\
\hline & $\mathrm{Mn}$ & 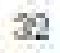 & $2 x+114$ & $1.00,600$ & 10 & $<\mathrm{DL}$ & \\
\hline & $\mathrm{Ni}$ & $m$ & $9 \mathrm{rl}+9.8 \mathrm{H}$ & {$[1,01,396]$} & 15it & $2.5 \pm 13.4$ & [T.AS, CLA] \\
\hline & $\mathrm{Pb}$ & 5 & $=\mathrm{DL}$ & & 15 & $\Leftrightarrow \mathrm{DL}$ & \\
\hline & Sn & $x$ & $=D L$ & & 1fit & $=\mathrm{DL}$ & \\
\hline & $v$ & 3 & $=\mathrm{DL}$ & & 15. & $=\mathrm{DL}$ & \\
\hline & $\mathrm{Zn}$ & $m$ & $7 M \pm \pi \mathrm{M}$ & D9, IDA] & 15 & $\Delta t a+150$ & 25.090 \\
\hline \multirow{14}{*}{$\begin{array}{l}\text { Digative } \\
\text { glind }\end{array}$} & Ait & 50 & $304 \pm 1$ thit & 1.11,7.04 & 24 & $3.40 \pm 1.00$ & $11,73,7.10$ \\
\hline & A! & 20 & $17.1+2.14$ & $716,413)$ & 24 & $11 t \pi \pm 3.07$ & {$[9,1 \mathrm{~d}]$} \\
\hline & $\mathrm{Cd}$ & 5 & $90.5 \pm 62.2$ & $72 \tau_{1} \mathrm{an}$ & 24 & $246 \pm 167$ & {$[3,68 d$} \\
\hline & Co & 3 & $\square 9 \pm 039$ & 131,211 & 24 & $10,5 \pm 9.04$ & [1 Ja, 35] \\
\hline & $\mathrm{Cr}$ & 5 & $0.14 \pm 0.0 \mathrm{~s}$ & [0.0, 0.28] & 24 & $0.27 \pm 4,16$ & [1]7,0.97] \\
\hline & $\mathrm{Cu}$ & 30 & $13 \pi \pm 1 \pi$ & $\left.495_{1}, 86\right]$ & 24 & $218 \pm 198$ & $24, c 211$ \\
\hline & Fiv & 5 & $180 \pm 100$ & {$[-4,4,4 z]$} & 24 & $91,7 \pm 121$ & {$\left[4 i, 1 D_{H}\right.$} \\
\hline & HE: & 3 & $\square J \pm \pm \square 2$ & D.M, LOS & 24 & $0.14 \pm \mathbb{a} .06$ & IIVA, 029 \\
\hline & Mn & 5 & $1.74 \pm 0,4$ & {$[1,11,281$} & 24 & $1.90 \pm 11.7 \mathrm{~S}$ & {$[04,3 \mathrm{tr}]$} \\
\hline & $\mathrm{Ni}$ & 30 & $0 \mathrm{st} \neq 024$ & $02,1,14$ & 24 & $3.54+3.68$ & $0.41,132$ \\
\hline & $\mathrm{Pb}$ & 5 & $007 \pm 004$ & $D, 0,015]$ & 24 & $0.2 \pm \pm 0.3$ & {$[19,1 \mathrm{n}]$} \\
\hline & $5 s$ & 3 & $B D \pm 7.45$ & $\operatorname{Lr}, 23$ & 24 & $\Delta \pi \pm 0.99$ & $D B g, 27 \mathrm{~B}$ \\
\hline & v & $\infty$ & $0 . \omega \pm 0.44$ & $021,1,2$ & 24 & $091 \pm 11.74$ & {$[0.22,20 t]$} \\
\hline & $7 a$ & 20 & $8 \mathrm{n}+38$ & 13,151 & 94 & $94 . \pm+4$ & 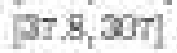 \\
\hline
\end{tabular}


Thith 3

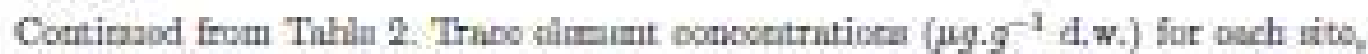

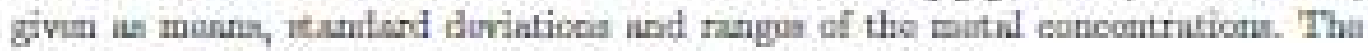

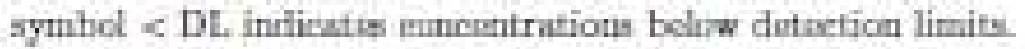

\begin{tabular}{|c|c|c|c|c|c|c|c|}
\hline \multirow[b]{2}{*}{ Orpu } & \multirow[b]{2}{*}{ Meted } & \multirow[b]{2}{*}{ in. } & \multicolumn{2}{|c|}{ Tismonis: } & \multicolumn{3}{|c|}{ Amutardint } \\
\hline & & & Mnan $\pm S D$ & Dhrige & $\mathrm{D}$ & Mres $+5 D$ & Runge. \\
\hline \multirow{14}{*}{ Gill } & $\mathrm{At}_{\mathrm{g}}$ & 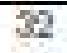 & QII 118 & [DD, DES] & 19 & $0.16 \pm 0.14$ & 1.44,0.6I \\
\hline & $\mathrm{As}$ & 2 & $210 \pm 5.74$ & $41, \pi 23]$ & 19 & $9.24 \pm 3.13$ & $3.43,147$ \\
\hline & $\mathrm{Cd}$ & $s$ & $4.37 \pm 1.5$ & 22,106 & 19 & $97.5 \pm 19.1$ & $523,10 \mathrm{~J}$ \\
\hline & Co & s & $0.1 \pm \pm 0 . \mathrm{H}$ & $\operatorname{Dos}, 0 \times$ & 19 & $0.69 \pm 0.90$ & $014,4.42$ \\
\hline & $\mathrm{Cr}$ & $\infty$ & $0.72 \pm 0.32$ & [D.19,200] & 19 & $0.90 \pm 0.62$ & 037,412 \\
\hline & $\mathrm{Cl}$ & 2 & $41 \theta+12 t$ & $20,76]$ & 19 & $190 \pm 84$ & $9,4 G$ \\
\hline & $\mathrm{Fr}$ & $s$ & $3.4 \pm 110$ & $k \mathrm{~B}, \mathrm{an}]$ & 19 & $11.5 \pm 5.00$ & $6,74,98$ \\
\hline & Hs & $n$ & $0.34 \pm 0.14$ & Dis, [1, 2$]$ & 19 & $0.31 \pm 4.2$ & 011,143 \\
\hline & Min & 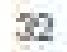 & $3.14 \pm 2.11$ & [1.SG, 144] & 19 & $2.19 \pm 0.5 s$ & $1.47,3,49$ \\
\hline & \$1: & 32 & $0.9 I+0.19$ & D. $15,0,0]$ & 19 & $0.74 \pm 0,90$ & {$[010,4$ EI } \\
\hline & $\mathrm{Pb}$ & 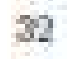 & $0.19+0.15$ & Dos, 000 & 19 & $0.12 \pm 0.12$ & $010,0,0$ \\
\hline & So & $n$ & $101 \pm 109$ & {$[0,4.90$} & 19 & $111 \pm 0 . \mathrm{E}$ & {$[0.59,360$} \\
\hline & $\mathrm{v}$ & $\infty$ & $=D L$ & & 19 & $0.08 \pm 0,0 s$ & 004, ‥29 \\
\hline & $7 n$ & $s$ & $5.4+5.1$ & $78,8,[68$ & 27 & $82 \pm \pm 6.2$ & III, 249 \\
\hline \multirow{14}{*}{ Musclo: } & $\mathrm{Mg}$ & 32 & $=D L$ & & 24 & $\because \mathrm{DL}$ & \\
\hline & Ai & 20 & $1 \mathrm{~J} \pm=3.7 \mathrm{n}$ & E4,25] & 23 & $14.4 \pm 2.44$ & 110.200 \\
\hline & $\mathrm{CH}$ & 3 & $0.21+0.14$ & {$[\times,[\pi]$} & $M$ & $0.93 \pm 0.7 !$ & III, $\mathrm{EL}$ \\
\hline & Co: & s & $-\mathrm{DI}$ & & 24 & $0.09 \pm \square .08$ & $0,04,035$ \\
\hline & $\mathrm{Cr}$ & 3 & $-D L$ & & 24 & $\because \mathrm{DI}$ & \\
\hline & Cu & 20 & $721+2.43$ & 290,142 & 28 & $6.30 \pm 1.20$ & 4.6d, $9 \mathrm{~A}$ \\
\hline & $\mathrm{Fe}$ & 30 & $9 \pi \mathrm{Tl} \pm 21$ & $4,2,2,5]$ & $2 d$ & $9.80 \pm 4.76$ & 530.221 \\
\hline & $\mathrm{H}_{\mathrm{I}}$ & 52 & $0.74 \pm 0.41$ & Dos, 194] & 24 & $0.2 t \pm 0.11$ & $011,0, \mathrm{nI}$ \\
\hline & $\mathrm{Mn}$ & $s$ & $-D L$ & & 24 & $\therefore \mathrm{DL}$ & \\
\hline & $\mathrm{si}$ & $m$ & $=D I$ & & 24 & $4 \mathrm{DL}$ & \\
\hline & $\mathrm{Pb}$ & $n$ & $=D L$ & & 14 & $\because \mathrm{DL}$ & \\
\hline & So: & s & $=D L$ & & 14 & $\therefore \mathrm{DL}$ & \\
\hline & $\mathrm{y}$ & 3 & $=D L$ & & 24 & $\because \mathrm{DL}$ & \\
\hline & $z$ & 20 & $\Delta I+\pi$ & $403,61.5$ & 29 & $\operatorname{sut} \pm 4.1$ & $\$ 1,4,10$ \\
\hline Gcninfs & $\mathrm{HE}$ & 5 & $0.21 \pm 0.14$ & 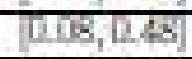 & & & \\
\hline
\end{tabular}


Thible 4

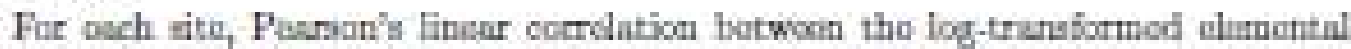
ecoumiration ind tho log-truraformot inutlo lingth.

\begin{tabular}{|c|c|c|c|c|c|}
\hline \multirow[b]{2}{*}{ Orman } & \multirow[b]{2}{*}{ Matil } & \multicolumn{2}{|c|}{ Thomanim } & \multicolumn{2}{|c|}{ Ambienthuin. } \\
\hline & & $\mathrm{r}$ & p-vilun & $r$ & p-nilu \\
\hline \multirow{9}{*}{$\begin{array}{l}\text { Brututial } \\
\text { hmerts }\end{array}$} & $\mathrm{Cd}$ & a.92 & bin & D.MT & 0.81 \\
\hline & $\mathrm{Cu}$ & 0.25 & D.11 & -004 & 4.9 \\
\hline & $\mathrm{Cr}$ & -1001 & 000 & -001 & 0.94 \\
\hline & $\mathrm{Cu}$ & -0.14 & D. 43 & -047 & 0.11 \\
\hline & Fer & -1.21 & 0,5 & -009 & 0.9 \\
\hline & $\mathrm{Hg}_{\mathrm{g}}$ & 0.44 & $\sin$ & 242 & a.11 \\
\hline & $\mathrm{Mr}$ & -1.29 & 0.12 & & \\
\hline & $\mathrm{Ni}$ & -0.20 & 010 & labs & 1.86 \\
\hline & $\mathrm{Zn}$ & 0.30 & Dou & +012 & a. \\
\hline \multirow{14}{*}{$\begin{array}{l}\text { Dibstive } \\
\text { ghnd }\end{array}$} & $\mathrm{Ag}_{\mathrm{g}}$ & ㅁ.18 & Lis & -10M & CDOI \\
\hline & A & 0.42 & 0.02 & -0.17 & 1.44 \\
\hline & $\mathrm{Cd}$ & -0.07 & $0, \pi 0$ & -146 & a.Do \\
\hline & $\mathrm{Cu}$ & -4.42 & 6on & -000 & $<001$ \\
\hline & $\mathrm{Cr}$ & -1.07 & 0.72 & $-00 \mathrm{~s}$ & 4001 \\
\hline & $\mathrm{Cu}$ & 004 & D.85 & -041 & H.Ea \\
\hline & $\mathrm{Fb}$ & -0.24 & 619 & - $00 \mathrm{ct}$ & $<001$ \\
\hline & $\mathrm{Hg}$ & 0.18 & 0.3 & $-03 n$ & 1.00 \\
\hline & Min & -0.21 & 0.22 & -0.13 & I.DA \\
\hline & Ni & - D.ca & Q8s: & -0.64 & coai \\
\hline & $\mathrm{PH}$ & 0.14 & 0.40 & -0.2 & 5001 \\
\hline & Si: & 0.22 & 0.25 & -0.04 & a.Bs \\
\hline & $Y$ & a.ts & 0,81 & $-0 \times 2$ & c001 \\
\hline & $7 n$ & -4.81 & 02 & -0.34 & 1.10 \\
\hline \multirow{14}{*}{ Gilln } & $\overline{A g}$ & [.7. & uc II,HI & -1241 & 11.08 \\
\hline & A & 0.19 & 0.20 & Din & 0.69 \\
\hline & $\mathrm{CI}$ & ㅂ.46 & $<\square .01$ & -147 & I,D4 \\
\hline & $\mathrm{Cr}$ & -L.DA & 0.2 & -0.47 & 1.04 \\
\hline & $\mathrm{Br}$ & -0.14 & 0.45 & 045 & 1.60 \\
\hline & $\mathrm{Cu}$ & -4.60 & 0.4 & -019 & 0.49 \\
\hline & Fo & B.,ot & D. 74 & -0.01 & I.LA \\
\hline & $\mathrm{Hg}$ & 0,44 & 001 & 023 & 0.17 \\
\hline & Mn & o여 & 0.87 & Dip4 & 1.es \\
\hline & Ni & $-0,2$ & 0.21 & -1.47 & 0.04 \\
\hline & $\mathrm{Pb}$ & 0.99 & 0.12 & Dis & I. 61 \\
\hline & Sol & -4.75 & D,as. & 041 & a.te \\
\hline & $\mathrm{v}$ & & & -028 & 1.24 \\
\hline & 7 & $0.0 \bar{T}$ & 0.6 & 0.25 & 0.12 \\
\hline \multirow{7}{*}{ Musele } & An & 매연 & 089 & List & 1.43 \\
\hline & $\mathrm{Cd}$ & 0.22 & 09 & IIE & 1.04 \\
\hline & $\mathrm{Cu}$ & & & -0.37 & 0.11 \\
\hline & Cui & 0.01 & D.gs & D.tT & a.4i \\
\hline & Eo & 029 & 0.21 & -1024 & 1.27 \\
\hline & $\mathbb{H}_{r}$ & Q.65 & 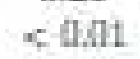 & Dens & -001 \\
\hline & 70 & 0.24 & 0.21. & DSA & 4001 \\
\hline Corinte & $\mathrm{Hg}$ & प्AII & Dis & & \\
\hline
\end{tabular}


Thiblo If

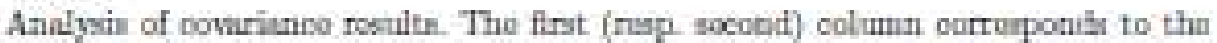

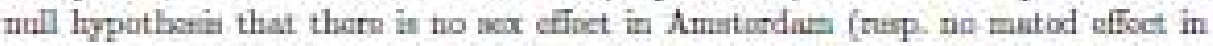

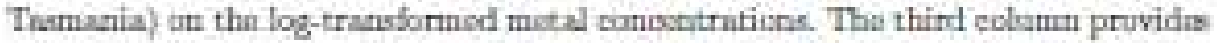

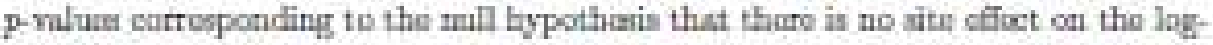

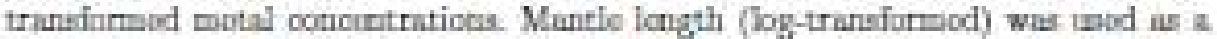
eckurinto in all tine ANCOWA

\begin{tabular}{|c|c|c|c|c|}
\hline Oryir & Mutul & $\begin{array}{l}\text { Bex dfoct } \\
\text { in Anutionim }\end{array}$ & $\begin{array}{l}\text { Mrited uffout } \\
\text { in Them anit }\end{array}$ & $\begin{array}{l}\text { Sibes } \\
\text { iffout }\end{array}$ \\
\hline \multirow{9}{*}{$\begin{array}{l}\text { Bratidill } \\
\text { barts }\end{array}$} & $\mathrm{Cd}$ & 0.74 & 120 & क्याII \\
\hline & Co & 0.37 & 1.93 & C.os \\
\hline & $\mathrm{Gr}$ & 0.99 & 4.2T & D.4 \\
\hline & $\mathrm{CH}$ & 0,77 & 1.76 & 09 \\
\hline & $\mathrm{Fs}$ & 0.86 & 1.17 & D.t5 \\
\hline & $\mathrm{Hz}$ & 022 & 010 & 0.7 \\
\hline & $\mathrm{Mn}$ & & 1,16 & \\
\hline & $\mathrm{Ni}$ & 0.12 & 1194 & Dof? \\
\hline & $\mathrm{Zn}$ & 0.47 & 10,94 & 0.0 \\
\hline \multirow{14}{*}{$\begin{array}{l}\text { Ifgetive } \\
\text { fland }\end{array}$} & $\mathrm{Me}$ & 0.99 & 125 & D.P. \\
\hline & A. & 0.26 & 1,12 & $<0.1$ \\
\hline & $\mathrm{Cd}$ & 029 & 1.24 & La \\
\hline & $\mathrm{Co}$ & 0.79 & $0.4 \mathrm{E}$ & - 011 \\
\hline & $\mathrm{Cr}$ & 0.05 & a.10 & 0.04 \\
\hline & Qu & 0.97 & $0.3 t$ & 0.41 \\
\hline & $\mathrm{Fa}$ & 0,At & 1.53 & 407 \\
\hline & $\mathrm{H} \mathrm{z}$ & 0.35 & A.79 & - 011 \\
\hline & $\mathrm{Mn}$ & 0.87 & all & 0.17 \\
\hline & $\mathrm{NI}$ & 0,44 & {$[1,7]$} & $-0,11$ \\
\hline & $\mathrm{Pb}$ & 0., तh & If.h & -011 \\
\hline & 50 & 0.62 & D.An & 0.4 \\
\hline & $v$ & 0.54 & I.54 & D.P \\
\hline & $\mathrm{Zn}$ & $0,7]$ & 1.MI & 0.40: \\
\hline \multirow{14}{*}{ Call } & $\mathrm{As}_{\mathrm{B}}$ & 0.17) & 1.12 & $=0191$ \\
\hline & $\mathrm{A}$ & 0.72 & I.1] & - 001 \\
\hline & $\mathrm{Cd}$ & 0.98 & 1.94 & -0.91 \\
\hline & $\mathrm{Co}$ & 0.34 & 1.14 & с 011 \\
\hline & $\mathrm{Cr}$ & 0,2 & 1.94 & 6001 \\
\hline & $\mathrm{Du}$ & 0.7f & 1.21 & -0.11 \\
\hline & $\mathrm{Fu}$ & 0.84 & a.5] & D.t4 \\
\hline & $\mathrm{Hz}$ & 0.96 & 1.21 & 0.8 \\
\hline & $\mathrm{Mn}$ & 0.23 & 10.12 & 0.14 \\
\hline & $\mathrm{Mi}$ & 0,97 & 178 & 0.18 \\
\hline & $\mathrm{Pb}$ & 0.94 & 0.49 & D.ST \\
\hline & Se & 0.94 & HA: & L.4 \\
\hline & $v$ & 0.41 & & \\
\hline & $\mathrm{Zn}$ & $0.4 i$ & I.kis & D.44 \\
\hline \multirow{7}{*}{ Mtucla } & 소 & 0.22 & III & 5.92 \\
\hline & $\mathrm{Cd}$ & 0.24 & 127 & cat \\
\hline & $\mathrm{Co}$ & $0.4 \mathrm{~B}$ & & \\
\hline & $\mathrm{Du}$ & $0.7 \mathrm{~T}$ & I.101 & 0,97 \\
\hline & $\mathrm{Fu}$ & 0.14 & 0.99 & D.25 \\
\hline & $\mathrm{Hz}_{z}$ & 0.48 & A.It & - 011 \\
\hline & $Z_{n}$ & 0.04 & WIT & D.45 \\
\hline Cunists & $\mathrm{Hz}$ & & [D.JI] & \\
\hline
\end{tabular}

